\title{
Characterization of metallothionein expression in response to cadmium in the 267-B1, normal prostate cell line
}

\author{
Madhuri G. Neriyanuri \\ West Virginia University
}

Follow this and additional works at: https://researchrepository.wvu.edu/etd

\section{Recommended Citation}

Neriyanuri, Madhuri G., "Characterization of metallothionein expression in response to cadmium in the 267-B1, normal prostate cell line" (2002). Graduate Theses, Dissertations, and Problem Reports. 1561. https://researchrepository.wvu.edu/etd/1561

This Thesis is protected by copyright and/or related rights. It has been brought to you by the The Research Repository @ WVU with permission from the rights-holder(s). You are free to use this Thesis in any way that is permitted by the copyright and related rights legislation that applies to your use. For other uses you must obtain permission from the rights-holder(s) directly, unless additional rights are indicated by a Creative Commons license in the record and/ or on the work itself. This Thesis has been accepted for inclusion in WVU Graduate Theses, Dissertations, and Problem Reports collection by an authorized administrator of The Research Repository @ WVU. For more information, please contact researchrepository@mail.wvu.edu. 


\title{
CHARACTERIZATION OF METALLOTHIONEIN EXPRESSION IN RESPONSE TO CADMIUM IN THE 267-B1, NORMAL PROSTATE CELL LINE
}

\author{
Madhuri G. Neriyanuri \\ Thesis submitted to the \\ Davis College of Agriculture, Forestry and Consumer Sciences \\ at West Virginia University \\ in partial fulfillment of the requirements \\ for the degree of \\ Master of Science \\ in \\ Genetics and Developmental Biology
}

Dr. Donald A. Sens, Committee Co-Chairperson

Dr. Joginder Nath, Committee Co-Chairperson

Dr. Scott H. Garrett

Genetics and Developmental Biology Program

Morgantown, West Virginia

2001

Keywords: 267-B1 cell line, Prostate, Metallothionein, Cadmium 


\begin{abstract}
CHARACTERIZATION OF METALLOTHIONEIN EXPRESSION IN RESPONSE TO CADMIUM IN THE 267-B1, NORMAL PROSTATE

CELL LINE
\end{abstract}

Madhuri G. Neriyanuri

The objective of the study was to characterize the mRNA and protein expression of the MT gene in response to $\mathrm{Cd}^{2+}$ exposure in the 267-B1 immortalized normal human neonatal prostate cell line. The cells were exposed to $18 \mu \mathrm{M} \mathrm{Cd}^{2+}$ for $4 \mathrm{hr}$ and rescued for 48hr in P4-8F normal medium. Samples were obtained at $0,1,2,4 \mathrm{hr}$ exposure and 4, 8, $12,16,24,36$, and $48 \mathrm{hr}$ recovery. Basal levels of mRNA for MT-1E, MT-1X, and MT2A genes in 267-B1 cells were similar to the expression of the G3PDH where as MT-3 had a low basal level expression. Exposure to $\mathrm{Cd}^{2+}$ following recovery in normal medium showed the expression of MT-1A, MT-1F, MT-1G genes and a 3 fold induction of MT$1 \mathrm{E}$ and a lesser induction of MT-1X and MT-2A. The basal level of MT-1/2 protein was found to be $3.2 \pm 0.17 \mathrm{ng} \mathrm{MT} /$ total protein with levels gradually increasing as a result of $\mathrm{Cd}^{2+}$ exposure. No MT-3 protein was induced on exposure to $\mathrm{Cd}^{2+}$. 


\section{ACKNOWLEDGEMENTS}

First, I would like to thank Dr. Donald A. Sens, for giving me the opportunity to work in his lab. Dr. Scott H. Garrett for his continuous guidance and patience in helping me in every aspect of this work. Dr. Seema Somji, who first taught me the techniques in the laboratory. Dr. Joginder Nath for giving me the opportunity to be a student and guiding me through the graduate program. I would also like to thank my friends in the lab who helped me in so many other ways.

Most importantly, I would like to thank my parents and brothers for supporting me and being the inspiration for doing higher studies. I would like to make special thanks to my husband, for constantly encouraging and supporting me in the completion of my Master's program. Without his support and love, this would not have been possible. 


\section{TABLE OF CONTENTS}

CHARACTERIZATION OF METALLOTHIONEIN EXPRESSION IN RESPONSE TO CADMIUM IN THE 267-B1, NORMAL PROSTATE CELL LINE ................................. i

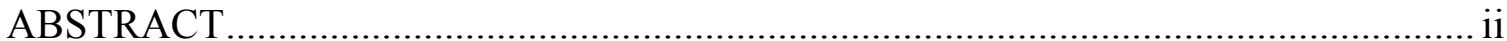

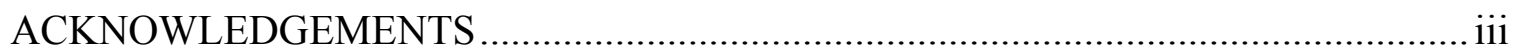

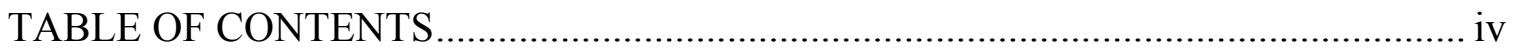

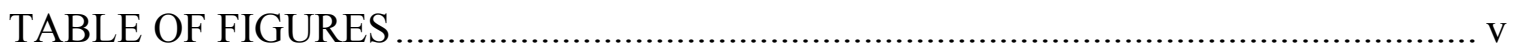

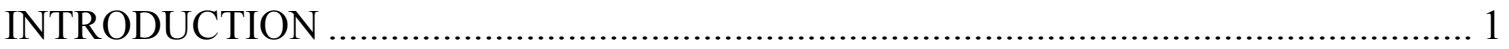

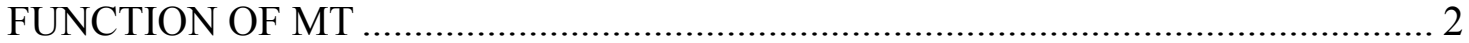

MT IN CELL PROLIFERATION AND APOPTOSIS ………………………...... 2

HOMEOSTASIS OF ESSENTIAL METALS ...................................................... 4

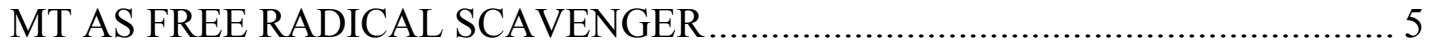

ROLE OF MT IN METAL DETOXIFICATION ……………………………..... 6

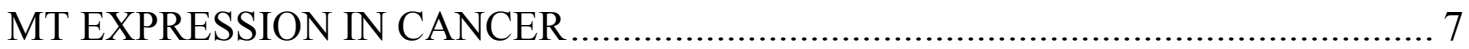

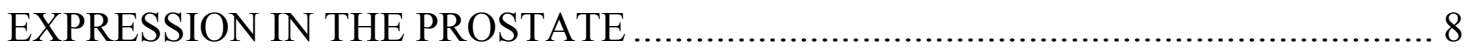

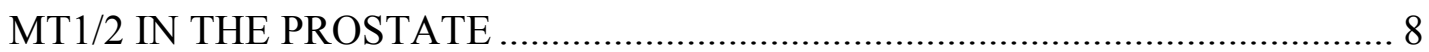

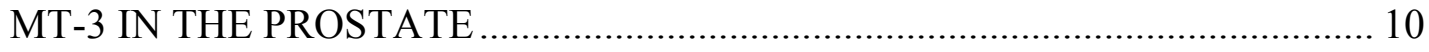

267-B1 NORMAL NEONATAL HUMAN PROSTATE CELL LINE ……………..... 12

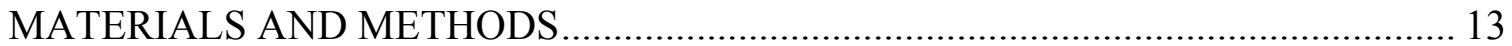

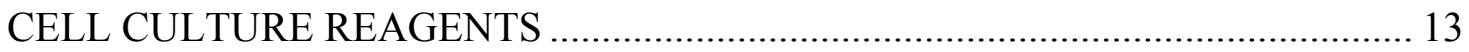

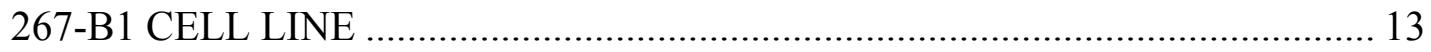

P4-8F SERUM FREE MEDIUM................................................................ 13

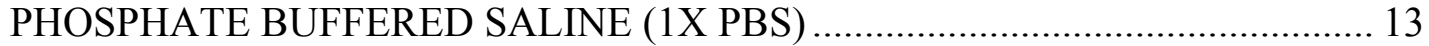

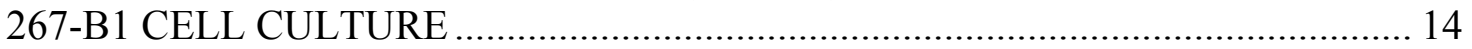

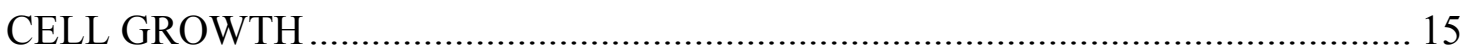

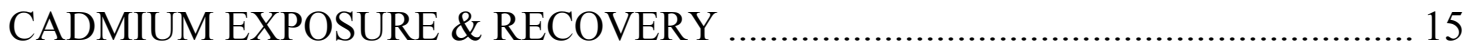

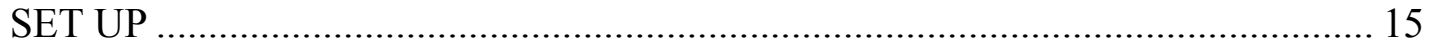

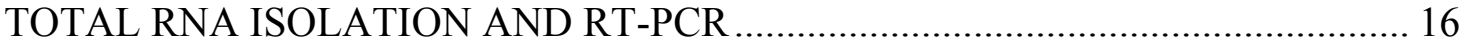

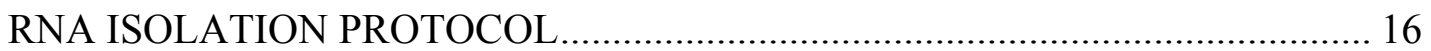

RNA QUANTITATION BY SPECTROPHOTOMETER …................................... 17

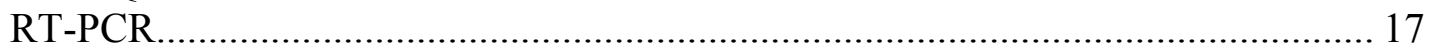

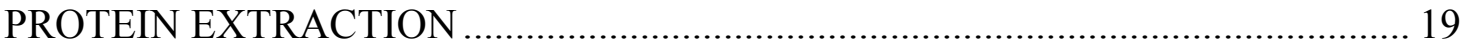

PROTEIN QUANTITATION ............................................................................ 19

THE ELISA TOTAL PROTEIN ASSAY USING THE BCA COPPER

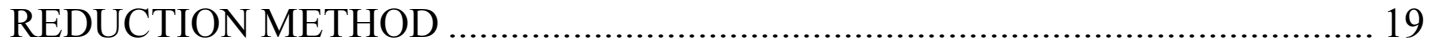

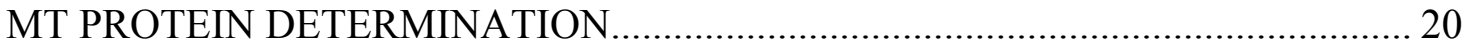

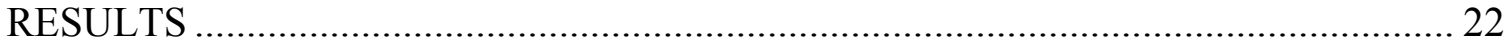

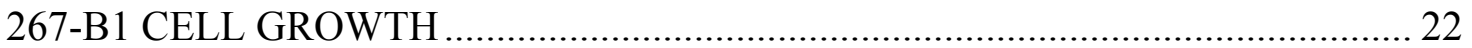

MT-mRNA AND PROTEIN EXPRESSION IN THE 267-B1 CELL LINE................ 22

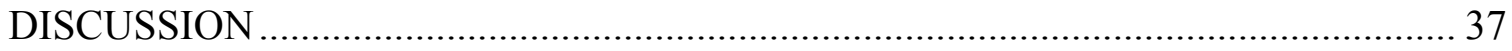

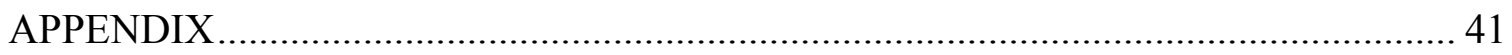

REAGENTS USED FOR PROTEIN CELL EXTRACTS ………............................. 41

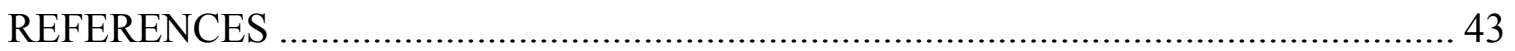

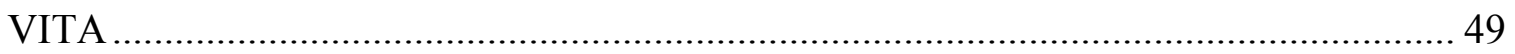




\section{TABLE OF FIGURES}

Figure 1 Phase-contrast photomicrograph of 267-B1 cells. Confluent monolayer of 267B1 normal neonatal prostate cells maintained in P4-8F serum-free growth medium.

Figure 2 Growth curve of 267-B1 cells. Confluent monolayer of 267-B1 normal neonatal prostate cells maintained in $\mathrm{P} 4-8 \mathrm{~F}$ serum-free growth medium.

Figure 3 Basal MT gene expression determined by RT-PCR using total RNA from 267B1 cells. Total RNA was purified from the 267-B1 cells and subjected to RT-PCR using primers specific for G3PDH, MT-1A, MT-1B, MT-1E, MT-1F, MT-1G, MT1H, MT-1X, MT-2A, MT-3, and MT-4. The reactions were sampled at 25, 30, 35, 40 cycles and the products visualized on $2 \%$ agarose gel containing $0.25 \mu \mathrm{g}$ per $\mathrm{ml}$ ethidium bromide.

Figure 4 Expression of MT-1A in 267-B1 cell line maintained in serum-free growth medium following exposure to $18 \mathrm{mM}$ cadmium for four hours. A) RT-PCR analysis of MT-1A (40 cycles). Gel shows gene expression at various time points during exposure and recovery from exposure to cadmium. B) Mean IOD values (+SEM) for MT-1A gene expression.

Figure 5 Expression of MT-1E in 267-B1 cell line maintained in serum-free growth medium following exposure to $18 \mathrm{mM}$ cadmium for four hours. A) RT-PCR analysis of MT-1E (30 cycles). Gel shows gene expression at various time points during exposure and recovery from exposure to cadmium. B) Mean IOD values (+SEM) for MT-1E gene expression.

Figure 6 Expression of MT-1F in 267-B1 cell line maintained in serum-free growth medium following exposure to $18 \mathrm{mM}$ cadmium for four hours. A) RT-PCR analysis of MT-1F (40 cycles). Gel shows gene expression at various time points during exposure and recovery from exposure to cadmium. B) Mean IOD values (+SEM) for MT-1F gene expression.

Figure 7 Expression of MT-1G in 267-B1 cell line maintained in serum-free growth medium following exposure to $18 \mathrm{mM}$ cadmium for four hours. A) RT-PCR analysis of MT-1G (40 cycles). Gel shows gene expression at various time points during exposure and recovery from exposure to cadmium. B) Mean IOD values (+SEM) for MT-1G gene expression.

Figure 8 Expression of MT-1X in 267-B1 cell line maintained in serum-free growth medium following exposure to $18 \mathrm{mM}$ cadmium for four hours. A) RT-PCR analysis of MT-1X (40 cycles). Gel shows gene expression at various time points during exposure and recovery from exposure to cadmium. B) Mean IOD values (+SEM) for MT-1X gene expression. 
Figure 9 Expression of MT-2A in 267-B1 cell line maintained in serum-free growth medium following exposure to $18 \mathrm{mM}$ cadmium for four hours. A) RT-PCR analysis of MT-2A (25 cycles). Gel shows gene expression at various time points during exposure and recovery from exposure to cadmium. B) Mean IOD values (+SEM) for MT-2A gene expression.

Figure 10 Expression of MT-3 in 267-B1 cell line maintained in serum-free growth medium following exposure to $18 \mathrm{mM}$ cadmium for four hours. A) RT-PCR analysis of MT-3 (40 cycles). Gel shows gene expression at various time points during exposure and recovery from exposure to cadmium. B) Mean IOD values (+SEM) for MT-3 gene expression.

Figure 11 Expression of MT-1/2 protein in 267-B1 cell line maintained in serum-free growth medium following exposure to $18 \mathrm{mM}$ cadmium for four hours. IOD of bands represent MT1/2 protein. 


\section{INTRODUCTION}

Metallothioneins (MT) are low molecular (6-7kDa), cysteine-rich, metal binding proteins (1). MT was first identified as a cadmium binding protein in equine kidney in 1957 and was subsequently purified and characterized by Kagi and Vallee (2). MT is characterized by its low molecular weight, high metal content, characteristic amino acid composition (high content of conserved cysteine residues and absence of aromatic amino acids) spectroscopic features indicating tetrahedral-thiolate complexes and metal thiolate clusters (3).

Based on their structural similarities MTs have been divided into 4 classes; MT-1 and MT-2, two ubiquitously expressed, heavy metal binding proteins, expressed in all eukaryotes including plants, yeast, worms, flies and some vertebrates. MT-3 was initially detected as the factor deficient in the brain of patients with Alzheimer's disease that inhibited neuronal cell growth in culture (4). It is predominantly expressed in glutaminergic neurons of the brain (5). MT-4 is expressed in the stratified squamous epithelium of skin, tongue and intestinal lining and appears to play an important role in the differentiation of these tissues (6).

MTs have two globular metal binding domains, $\alpha$ (in the $C$ terminal region) and $\beta$ (in the N-terminal region), that are conserved among all four isoforms. MT-3 contains an additional $\mathrm{C}$ terminal hexapeptide and proline residues at position 7 and 9 that probably impart its growth inhibitory properties to neuronal cells in culture (7). The structures of all four isoforms are highly conserved at the amino acid and nucleotide levels.

Human MT genes are clustered at a single locus on chromosome 16 (16q13) (8) and at least 10 of the 17 genes so far identified, are functional. These encoded multiple isoforms 
of MT-1 and, usually, a single form of MT-2 (9). Only single genes for MT-3 and MT-4 have been detected. The expression and the gene sequence of the functional genes have been reported for MT-1A, MT-1B, MT-1E, MT-1F, MT-1G, MT-1H, MT-1X, MT-2A, MT-3, and MT-4, the non-functional MT genes are MT-1C, MT-1D, MT-1I, MT-1J, MT$1 \mathrm{~K}, \mathrm{MT}-1 \mathrm{~L}$ and MT-2B (3). MT-3 is preferentially expressed in the brain (5), although recently it has been detected in the maternal decidium, reproductive tissues, as well as the kidney $(10,11)$. The MT-4 gene from mouse and human has been cloned and the expression of the gene appears to be limited to squamous epithelial cells (6).

\section{FUNCTION OF MT}

MT has a relatively rapid rate of turnover and this has been taken as evidence for a regulatory function. Detailed analysis of the structure of MT has been helpful in delineating some of the possible biological roles for this protein. The metal thiolate clusters within the MT molecules allow rapid exchanges of metal ions between clusters and with other MT molecules (3). Hence, it is thought that this characteristic, which appears to be unique to MT, aids the transfer of metal ions and is fundamental to its biological role (12). Functions of MTs include metal absorption/excretion, metal detoxification, apoptosis, and modulation of the intracellular redox balance.

\section{MT IN CELL PROLIFERATION AND APOPTOSIS}

A number of investigations suggest that MT plays an important role in cell proliferation. For instance, in mammals high levels of MT expression have been detected

during later stages of gestation and neonatal periods (3); MT levels are also transiently elevated during liver regeneration as well as in liver and kidney of uninephrectomized rats. Increased MT levels have also been reported in vitro during exponential cell growth 
(13). MT is mainly a cytoplasmic protein but it is also present in the nucleus during cell proliferation and development (14). For example, MT has been detected in both the nucleus and cytoplasm of human fetal hepatocytes, and the levels of MT increase with gestational age (14). Cellular localization of MT appears to be cell cycle specific because it peaks in the nucleus during $\mathrm{S}$, and $\mathrm{G}_{2} / \mathrm{M}$ phases while maximal expression in the cytoplasm occurs during $\mathrm{G}_{0}$ and $\mathrm{G}_{1}$ phases (13). MT is located mainly in the cytoplasm of both human fetal and adult renal proximal tubule cells, but no correlation between gestational age, level of MT or cellular localization in the kidney has been found, suggesting that the distribution and expression on MT during development may be organ specific (15). Thus, it would appear that nuclear localization of MT is either cell type specific or characteristic of a particular proliferative state.

MT may also play a role as a zinc donor where required, such as in activating zinc-finger transcription factors. The elevated concentrations of MT during proliferation could be related to the increased demand for certain metals such as copper and zinc. A number of MT inducers, such as glucocorticoids, lipopolysaccharides, steroids, hormones, cytokines and tumor necrosis factors, can influence apoptosis in certain cells. These experimental data suggest that MT plays a role during the apoptotic process. Cells from MT-null mice have been found to be more susceptible to apoptosis after exposure to tert-butyl hydroperoxide and anti cancer agents than normal MT-expressing cells (16). In human, MT expression and reduction in the number of apoptotic cells have been demonstrated in liver tumors, laryngeal hyperplastic lesion and squamous cell carcinoma of the tongue (3). In summary over expression of MT appears to protect against apoptotic cell death, while lack of MT increases cell susceptibility to apoptosis. 
With the involvement of MT in cell proliferation and apoptosis, it is not surprising that the possible role and significance of MT in cancer has also received considerable attention. The levels of MT expression have been investigated in a wild variety of tumors (17). The MT content in tumors has been related to the proliferative states of the cells, although it is also a function of the degree of maturation and differentiation of the tumor.

\section{HOMEOSTASIS OF ESSENTIAL METALS}

MT is thought to be involved in homeostasis of the essential metals, copper and zinc, as it is the major zinc and copper binding protein in many tissues, and there is a close relationship between tissue MT and zinc content $(18,3)$. The importance of zinc is evident from its role as a major component of many enzymes and cell processes and from the severe pathology observed in response to zinc deficiency in skin, neurological, immune, and reproductive tissues (19). Mice over-expressing MT and also MT knockout mice have been used as models to test this function of MT in vivo. For example, transgenic mice with over-expressing MT-1 are more resistant to zinc deficiency. This has been attributed to a larger pool of zinc bound to MT, thereby supporting the view that MT is an important source of intracellular zinc.

A hypothesis was proposed that MT acts as a chaperone during synthesis and modulation of metalloproteins. Metal requiring apoenzymes can abstract metals from MT as demonstrated in vitro (20). Glutathione (GSH) can form a complex with MT; release of zinc from MT mediated by interactions with GSH and Glutathione-disulfide (GSSG) through S-thiolation (21). Evidence suggests that zinc released from MT is facilitated by direct-coupled interaction of GSH and GSSG with MT via the thiolate ligands that confer redox activation of zinc clusters resulting in oxido-reduction MT-Zn complexes. MT 
therefore may be acting as a sensor of the localized intracellular redox balance and may itself influence redox balance through GSH and the known antioxidant properties of zinc. It has been suggested that the control of cellular zinc distribution as a function of the energy state of the cell is the long sought role of MT (22). In cells in culture, MT can donate $\mathrm{Cu}$ to $\mathrm{Cu}-\mathrm{Zn}$ superoxide dismutase and at least in vitro the $\mathrm{Cu}-\mathrm{MT}$ interaction is also under redox control (23). These facts support that MTs act as physiological transporters of essential metals (such as $\mathrm{Cu}$ and $\mathrm{Zn}$ ) and that this distribution is regulated in redox-sensitive manner.

\section{MT AS FREE RADICAL SCAVENGER}

MT is induced by treatments like hyperoxia, ionizing radiations or cold exposure and by substances like ethanol, paraquat, tert-butyl hydroperoxide that cause oxidative stress. This suggests that MT may protect against reactive oxygen and nitrogen species. Moreover, animal or cells in culture that are deficient in MT isoforms exhibit greater susceptibility to oxidative stress caused by electrophilic mutagens, antineoplastic drugs, nitric oxide as well as cadmium (24).

Over-expression of MT reduces the sensitivity of cells and tissues to free radical damage and MT genes are transcriptionally activated in cells and tissues in response to oxidative stress (25). The mechanism by which MT protects against oxidative stress is suggested by the idea that the thiolate clusters of MT are primary targets for the reaction of hydroxyl radicals. It is suggested that hydrogen peroxide, superoxide anions, and peroxyl radicals interact with MT and result in oxidative modification of the protein, thus suggesting that in vivo this may affect the capacity of the MT to bind metals. Free metals $(\mathrm{Cd}$ and $\mathrm{Zn})$ interact with in the cell membrane and interfere with iron redox reactions 
(by either competing for binding sites or causing structural changes which reduce binding) thereby reducing the conversion of $\mathrm{H}_{2} \mathrm{O}_{2}$ to $\mathrm{OH}$ free radicals. A similar effect was proposed where free radicals were thought to interact with the MT to release metals and influence redox events. For example, $\mathrm{Cu}-\mathrm{MT}$ enhances lipid peroxidation initiated by organic hydro peroxides, suggesting that MT may act as an antioxidant or a pro-oxidant depending on its association with metals (3).

\section{ROLE OF MT IN METAL DETOXIFICATION}

MT plays a major role in detoxification of metals like $\mathrm{Cd}^{2+}$ and $\mathrm{Hg}^{2+}$. After exposure to various metals, there is a significant increase of MT in tissues such as kidney, liver and intestine. Various cell types have also been shown to accumulate MT after exposure to metals. Much of the information regarding metal toxicity has been obtained from studying the toxic effects of $\mathrm{Cd}$, which accumulates in body under normal conditions. For example, tolerance to $\mathrm{Cd}$ following low dose pretreatment with cadmium/zinc is directly related to the concentration of hepatic MT in rats $(26,27)$. Also, Cd-resistant cell lines express very high levels of MT and these cells show increased resistance to the toxic effects of several other metals.

The mechanism whereby metal-induced MT reduces the toxicity of metals may be

dependent on the metal and in addition they may be cell type specific. Studies using transgenic mice that either over-express or are deficient in MT have provided further insight in to the role that MT plays in the protection against metal toxicity. It has been found that MT-1- over-expressing mice (which carry 56 copies MT-1 gene) are more tolerant to hepatotoxicity and lethality caused by cadmium than control mice (28). And, 
mice with disrupted MT-1 and MT-2 genes (MT null mice) are more sensitive to cadmium and mercury induced toxicity than control mice.

Induction of $\mathrm{MT}$ in the kidney protects against $\mathrm{HgCl}_{2}$ - mediated nephrotoxicity. The protective effect of MT against $\mathrm{HgCl} 2$ toxicity appears to be due to the MT binding Hg in the cytosol (24).

\section{MT EXPRESSION IN CANCER}

The role of MTs in tumor biology can be looked at from 3 perspectives. The first relates to the possible association of MT deficient states with sensitivity to carcinogenic effects of heavy metals and other environmental carcinogens. Kondo and Woo examined the effect of the loss of MT expression on the cytoxicity of anticancer agents and mutagens using embryonic fibroblast cells from transgenic mice with targeted disruption of MT-1 and MT-2 genes (29). These MT null cells expressed no detectable MT, compared to wild type cells. MT null cells showed enhanced sensitivity to $2 \mathrm{hr}$ exposure to anticancer agents like cisplatin, melphalan, bleonycin and cytarabine. As a result of this, the basal expression of the DNA damage response genes was elevated in MT null cells compared to wild type cells. Anticancer drug treatment, however, did not produce a greater increase in DNA damage response genes in MT null mice compared to wild type cells. These results supported the hypothesis that endogenic MT levels affect the sensitivity of cells to mutagens and anticancer drugs. The second perspective relates to the possible role of MT over-expression in resistance of tumors to anti-cancer therapy. The development of resistance to antineoplastic agents significantly restricts the efficacy of these agents. Therefore, identification of the mechanisms of antineoplastic drug resistance becomes a critical precursor to design new treatment strategies for cancer (30). 
The third perspective pertains to the demonstration that antibodies can be used to immunochemically determine the expression of MT protein in archival paraffinembedded tissues. This allows retrospective studies of MT-3 expression status in a variety of human tumors, showing an association of MT-3 over-expression with the type and grade of tumor. For example, the E-9 antibody used in majority of studies for detection of immunocytochemistry of tumor associated MT over-expression is well characterized for specificity. The antibody is able to recognize both MT-1 and MT-2 isoforms (17). The expression of MT is correlated to the histological grade of the tumor; with the well-differentiated, low Gleason score tumor having lower MT immunoreactivity than the poorly differentiated and high Gleason score tumors. In skin carcinomas and melanomas, cervical carcinomas, acute lymphoblastic leukemia, MT-3 over-expression appears to be predominantly associated with the more malignant, highgrade tumors. In colonic and fibroblastic skin tumors, MT over-expression is associated with more differentiated low-grade tumors. And in ductal breast carcinoma, MT overexpression has been related to locally invasive primary carcinoma of poor histological type and grade.

\section{EXPRESSION IN THE PROSTATE}

\section{MT1/2 IN THE PROSTATE}

In a study to confirm the immunohistochemical localization of MT1/2 in the human prostate using the commercially available E-9 antibody preparation, the general finding was that MT immunoreactivity was localized in the cytoplasm and nucleus of glandular epithelial cells. The immunoreactivity of MT was found to be most intense in the peripheral zone, moderate in the transitional zone, and weak in the central zone; 
however, epithelial cells in all zones showed a large variability in MT staining intensity. Marked immunostaining for MT was noted in areas with inflammation in granulomatous chronic prostatitis. Increased intensity of E-9 MT immunostaining was also noted in the areas of fibromuscular hypertrophy and in areas of chronic inflammation. In prostate cancer, the expression of MT was correlated to tumor grade, and that MT has a wide range of expression in the prostate cancer.

Human MT-1 protein can be theoretically produced from mRNA originating from any combination of the several active MT-1 isoform genes, designated MT-1A, MT-1B, MT-1E, MT-1F, MT-1G, MT-1H and MT-1X, while MT-2 protein is generated from a single gene, designated MT-2A. It was found that expression of MT1/2 protein in the normal human prostate is supported by transcription of mRNA originating from, at minimum, the MT-1A, MT-1E, MT-1X and MT-2A genes. To determine if the expression of the MT-1 and MT-2 isoforms are altered in prostate cancer, both when compared to the expression pattern present in the normal tissue and between individual cancers, the expression of the MT-1A, MT-1E, MT-1X and MT-2A genes was assessed using total RNA isolated from paraffin embedded tissues from five cases of advanced prostate cancer known to immunohistochemically overexpress the MT protein. The finding that MT-1X mRNA was not expressed in any of the five prostate cancer specimens demonstrated that MT isoforms expression is altered from the expression pattern present in normal prostate tissues (31). The evidence that MT isoform gene expression was altered among prostate tumors was provided by the finding that MT-1A and MT-1E expression was present in some, but not all, of the five advanced cases of prostate cancer. These findings suggest that the clinical significance of MT expression in 
human prostate cancer might be further defined if specific MT gene expression patterns were known for individual tumors.

\section{MT-3 IN THE PROSTATE}

The study of MT-3 expression in the normal and cancerous human prostate can be of significant importance for several reasons. First, MT-3 also has a high affinity for binding with the metal, cadmium, and both occupational and environmental studies have suggested a possible role of cadmium in prostate cancer etiology (32). Secondly, MT-1 and MT-2 family members have been shown to be expressed in epithelium of the normal human prostate and they exhibit an altered pattern of expression in prostate cancer, with expression correlating with Gleason score. Similarly MT-3 expression could also define a pattern of expression correlating with the Gleason score. And lastly MT-3 has been shown to posses a neuronal cell grown-inhibiting activity, which is not duplicated by the other human MT classes (33). The demonstration that MT-3 is expressed in the human prostate, prostate cancer and prostate cancer- derived cell lines, suggests additional means by which prostate epithelial cell growth might be controlled.

Immunohistochemical localization of MT-3 was done by using an affinitypurified antibody against MT-3, which was generated using the dodecapeptide GGEAAEAEAEKC (corresponding to MT-3 amino acid, 53-64, which contain the MT-3 unique amino acid insert) conjugated through the C-terminal cysteine sulfhydryl group to keyhole limpet hemocyanine, using maleimidobenzoyl-N-hydroxysuccinimide ester (34). The results observed in the normal prostate were, the acinar cells demonstrated no immunoreactivity for MT-3 in normal glands from either the peripheral zone or central zone. The basal cells in these acinar structures demonstrated weak cytoplasmic staining, 
with some instances of nuclear localization. In the fibromuscular stromal cells, very weak staining was observed, particularly in the more compact stroma of the central zone. The MT-3 immunoreactivity of the stroma was increased in areas of fibromuscular benign prostatic hypertrophy. Moderate MT-3 immunoreactivity was observed in the inflammatory cells, particularly the histiocytic cells with in granulomatous foci. In areas of inflammation, increased staining of MT-3 was demonstrated in epithelial cells of the acini and prostatic ducts.

RT-PCR analysis of MT-3 indicated that MT-3 mRNA is very vividly expressed in the normal human prostate (below that of two commonly monitored housekeeping genes, G3PDH and $\beta$-actin). Immunoblot determination of MT-3 protein content in six normal human prostate specimens showed a large range of MT-3 expressions that varied from a low of $4.0 \mathrm{pg} \mathrm{MT} / \mu \mathrm{g}$ total protein to a high of $24.6 \mathrm{pg} \mathrm{MT} / \mu \mathrm{g}$ total protein.

Increase in MT-3 immunoreactivity was demonstrated in prostatic intraepithelial neoplasia (PIN) within the acinar cells. In prostatic adenocarcinoma, MT-3 immunostaining was positive within malignant cells; MT-3 expression was enhanced and found to be highly variable in PIN lesion and primary prostate cancer cells. MT-3 immunoreactivity showed a correlation with the histological grade of the tumor, with the well differentiated, low Gleason score tumors having lower MT-3 immunoreactivity than the poorly differentiated and high Gleason score tumors.

Two of the commonly utilized prostate cancer cell lines, DU-145 and LNCaP, were demonstrated to express mRNA for MT-3, while the PC-3 cell line demonstrated no expression of MT-3. Analysis of MT-3 protein expression indicated that both the LNCaP and DU-145 cells expressed the MT-3 protein in amounts similar to those found in the 
tissue specimens. The findings that MT-3 immunoreactivity elevated in PIN lesions and in the primary prostate cancer cells suggested a possible dysregulation of MT-3 expression in prostate cancer. It is proposed that this will entail retrospective determination if MT-3 is enhanced in all PIN lesion and primary cancers, and if the degree of expression can be correlated to tumor grade, clinical stage or protein outcome (34).

\section{7-B1 NORMAL NEONATAL HUMAN PROSTATE CELL LINE}

The cell line used in this study was obtained from the Biological Research Faculty and Facility, Inc with the designation 267-B1. 267-B1 is an immortalized normal human neonatal prostatic epithelial line isolated as a single colony of pRSV-T transfected NP-2s cells (neonatal human prostatic epithelial cells). The cells were grown in P4-8F serum free medium. This cell type was chosen because the prostate represents an organ that is affected by the $\mathrm{Cd}^{2+}$ exposure in both animals and humans. The objective of this study is to define the regulation of expression of the MT gene family in the normal human prostate cell line, 267-B1 exposed to the metal, cadmium. 


\section{MATERIALS AND METHODS}

\section{CELL CULTURE REAGENTS}

\section{7-B1 CELL LINE}

This cell line was obtained from the Biological Research Faculty and Facility, Inc. 267-B1 is an immortalized normal human neonatal prostatic epithelial line isolated as a single colony of pRSV-T transfected NP-2s cells (neonatal human prostatic epithelial cells).

\section{P4-8F SERUM FREE MEDIUM}

This serum-free (ready-to-use) medium was designed to grow the immortalized normal prostatic cell line 267-B1 and was obtained directly from Biological Research Faculty \& Facility, Inc., Ijamsville, MD. It consists of P4, a modified basal medium

PFMR4 without the trace element concentrate and with $\mathrm{Ca}^{2+}$ concentration reduced to 0.5mM, supplemented with $30 \mathrm{nM} \mathrm{H}_{2} \mathrm{SeO}_{3}$ (Johnson Matthey Chemicals, Ltd., Hertfordshire, England), 5ng/ml epidermal growth factor (Collaborative Research), $5 \mathrm{ug} / \mathrm{ml}$ insulin, $0.28 \mathrm{uM}$ hydrocortisone, $0.5 \mathrm{uM}$ phosphoethanolamine, $0.1 \mathrm{nM}$ cholera toxin (Calbiochem), $250 \mathrm{ug} / \mathrm{ml} \mathrm{BSA} \mathrm{(Sigma),} \mathrm{and} \mathrm{0.5 \%} \mathrm{BPE} \mathrm{(bovine} \mathrm{pituitary} \mathrm{extract)}$

\section{PHOSPHATE BUFFERED SALINE (1X PBS)}

To make 5 liters of 1x PBS, $42.5 \mathrm{~g}$ of $\mathrm{NaCl}$ (Sigma, Cat No. S-9888) was combined with $0.6 \mathrm{~g} \mathrm{Na}_{2} \mathrm{HPO}_{4}$ (Fisher Scientific, Cat No. S-374) and $0.12 \mathrm{~g} \mathrm{NaH}_{2} \mathrm{PO}_{4}$ (Fisher Scientific, Cat No. S-369) in a total volume of 5 liters of deionized water. PBS was aliquoted into $500-\mathrm{ml}$ bottles, autoclaved, and stored for up to one year at $4^{\circ} \mathrm{C}$. 


\section{7-B1 CELL CULTURE}

The 267-B1 normal prostate cells were obtained from the Biological Research Faculty and Facility, Inc. These cells were grown in T-75 flasks (Corning®, Cat No. 430720). The growth surface of the T-75 flask was treated with FNC coating mixture, a collagen matrix to promote cell attachment and subculture. Excess of the coating mixture was discarded and the flasks were allowed to air dry. Confluent normal prostate cultures were used in subculturing the cells. To passage the cells, media was removed from the flask maintained and the flasks were rinsed with $7.5 \mathrm{ml}$ of sterile PBS. The PBS washes were discarded and the cells of each flask were treated with $3 \mathrm{ml}$ of trypsin-EDTA (Gibco-BRL, Cat No. 25300-062). The cells were trypsinized until the cells appeared completely dissociated (approximately 5-10 min). The cell suspensions were collected in a 15-ml conical tube and the flasks were rinsed with $9 \mathrm{ml}$ of PBS. The PBS washes were transferred to the tube containing the trypsinized cells. $1 \mathrm{ml}$ of $5 \%$ Fetal Bovine Serum was added to the cell suspension to stop the tryptic action. The tube was centrifuged for 5 min at $10,000 \mathrm{rpm}$. The supernatant was removed and the cell pellet was thoroughly resuspended in $10 \mathrm{ml}$ of complete serum-free medium. A 1-ml aliquot of the cell suspension was transferred to a T-75 flask that was precoated with FNC coating Mix, containing $14 \mathrm{ml}$ of the $\mathrm{P} 4-8 \mathrm{~F}$ medium. The flasks were routinely subcultured (1:10 ratio) unless stated otherwise. Subcultured flasks were fed with $15 \mathrm{ml}$ of fresh medium $24 \mathrm{hr}$ following subculture and every $72 \mathrm{hr}$ thereafter and maintained under standard conditions of $37^{\circ} \mathrm{C}$ in a $5 \% \mathrm{CO}_{2}: 95 \%$ atmosphere. 


\section{CELL GROWTH}

Growth studies were initiated over a period of 10 days. Five 6-well plates were seeded at a ratio of 20,000 cells/well. The cells were fed every $48 \mathrm{hrs}$ and maintained at a constant temperature of $37^{\circ} \mathrm{C}$ in a $5 \% \mathrm{CO} 2: 95 \%$ atmosphere. Cell counts were determined by the automated counting of 4', 6-diamidino-2phenylindole (DAPI)-stained nuclei of cells fixed and processed at days $1,2,3,4,5,6,7,8,9$, and 10 of cell growth. In this procedure, the nuclear stain DAPI and Kontron KS 400 image analysis software (Kontron Elektronik, Newport Beach, CA) was used. At the indicated time points, wells containing the mono-layers were rinsed with phosphate-buffered saline (PBS), fixed for $15 \mathrm{~min}$ in $70 \%$ ethanol, rehydrated with PBS, and stained with $10 \mu 1$ DAPI $(10 \mu \mathrm{g} / \mathrm{ml}$ in PBS). For analysis, each well was examined under epifluorescent illumination at $40 \times$ magnification on a Zeiss Axiovert 35 (Carl Zeiss Inc., Thornwood, NY) linked to the computer with an Optronics DEI 470CCD camera (Optronics, Goleta, CA) for each time point, a minimum of 20 fields per well and three wells per data point were determined. The doubling time for the $267-\mathrm{B} 1$ normal prostate cells was calculated using the formula $(\ln 2) /($ slope $\times 24)=$ time (hr) for doubling cell number. The slope was derived from a linear regression of ln [cell number] plotted against number of days of cell growth.

\section{CADMIUM EXPOSURE \& RECOVERY}

\section{SET UP}

Twelve 6-well plates were seeded at a 1:4 subculture ratio using serum-free 267B1 cultures. The growth surface was coated with FNC coating Mix prior to the seeding of the cells. The cells were fed every $72 \mathrm{hr}$ until the cells were confluent. The final feeding came $24 \mathrm{hr}$ prior to starting the experiment. Preliminary pilot studies were performed to 
determine the approximate concentrations of metal salt resulting in the 267-B1 prostate cell toxicity over a 4-hr period of exposure and subsequent recovery of cells in serumfree growth medium for $48 \mathrm{hrs}$. The concentration selected for this experiment was $18 \mu \mathrm{M}$ $\mathrm{Cd}$ as $80-85 \%$ of cells survived by the end of $48 \mathrm{hrs}$ of the recovery phase. Confluent 267-B1 normal prostate cells were treated with this metal concentration and cell viability, MT-mRNA and MT protein were determined at $0 \mathrm{hr}, 1 \mathrm{hr}, 2 \mathrm{hr}, 4 \mathrm{hr}$ exposure and then the cells were recovered with normal medium after $4 \mathrm{hr}, 8 \mathrm{hr}, 12 \mathrm{hr}, 16 \mathrm{hr}, 24 \mathrm{hr}, 36 \mathrm{hr}$ and 48hr. A $24 \mathrm{hr}$ control was also determined. Experiment was conducted in triplicates.

\section{TOTAL RNA ISOLATION AND RT-PCR}

Total RNA was isolated according to the protocol supplied with TRI REAGENT (Molecular Research Center, Inc., Cincinnati, $\mathrm{OH}$ ) as described below.

\section{RNA ISOLATION PROTOCOL}

Medium was removed from the wells and $1 \mathrm{ml}$ of TRI Reagent was added to each well. The resultant lysates were stored at room temperature for 5-10 minutes to completely dissociate nucleoprotein complexes. Cell lysates were then passed several times through a $1 \mathrm{ml}$ pipette to shear DNA, and transferred to an RNase free microfuge tube. Cell lysates were immediately stored at $-70^{\circ} \mathrm{C}$. Samples were removed from the - $70^{\circ} \mathrm{C}$ freezer and thawed at room temperature. Then $100 \mu 1$ of Bromochloropropane (BCP-Cat No. BP-151) was added to each sample extract and vortexed well and left aside for about 10 minutes. The samples are then centrifuged in a table-top counter for $10 \mathrm{~min}$ at $14000 \mathrm{rmp}$ at $4^{\circ} \mathrm{C}$. The top layer (RNA) was transferred into an RNase free tube and $0.5 \mathrm{ml}$ isopropanol was added. The contents were mixed well and kept aside for $10 \mathrm{~min}$ and centrifuged again at $14000 \mathrm{rmp}$ at $4^{0} \mathrm{C}$. The resulting supernatant was removed and 
the left over RNA pellet was washed with $70 \%$ ethanol. The pellet was washed with ethanol 2-3 times and then left to air dry. $40 \mu 1$ of water was later added to the dry pellet and stored in $-70^{\circ} \mathrm{C}$ immediately.

\section{RNA QUANTITATION BY SPECTROPHOTOMETER}

The concentration and purity of the samples was determined using spectrophotometer scan in the UV region. The RNA sample was thawed and $3 \mu 1$ of RNA was added to $97 \mu 1$ of $1 \mathrm{mM}$ RNase free phosphate buffer $(\mathrm{pH} 7.0)$. The spectrophotometer cuvet was cleaned with $\mathrm{dH}_{2} \mathrm{O}$ and $100 \mu \mathrm{l}$ of RNase free phosphate buffer (blank) was added. The absorbence was recorded at $260 \mathrm{~nm}, 280 \mathrm{~nm}$, and the $260 / 280$ ratio obtained. Phosphate buffer was removed and a second volume of $100 \mu 1$-phosphate buffer was added and absorbence recorded again. If the absorbence was the same, it was set as a blank. If not, cuvet was cleaned and phosphate buffer added and absorbences recorded again till they were the same. The blank was removed and the first sample of RNA was added and absorbence recorded at $260 \mathrm{~nm}, 280 \mathrm{~nm}$, and the $260 / 280$ ratio obtained. Absorbence of all RNA samples was obtained in this manner. The RNA concentration was calculated using the following equation.

RNA Concentration $=$ Absorbance at $260 \mathrm{~nm} \mathrm{X} 40 \mu \mathrm{g} / \mathrm{mL} \mathrm{X} \mathrm{volume} \mathrm{of} \mathrm{the} \mathrm{sample}(0.1 \mathrm{~mL})$ Volume of the RNA sample $(3 \mu \mathrm{L})$

\section{RT-PCR}

Total RNA $(0.1 \mu \mathrm{g})$ was reverse transcribed using murine leukemia virus reverse transcriptase (50 units) in $1 \mathrm{X}$ PCR buffer (50 $\mathrm{mM} \mathrm{KCl}$ and $10 \mathrm{mM}$ Tris-HCl, $\mathrm{pH} 8.3$ ), $5 \mathrm{mM} \mathrm{MgCl}_{2}, 20$ units RNase inhibitor, $1 \mathrm{mM}$ each of the dNTPs, and $2.5 \mu \mathrm{M}$ random hexanucleotide primers. The samples were reverse transcribed for 20 min at $42^{\circ} \mathrm{C}$, followed by 5 min denaturation step at $99^{\circ} \mathrm{C}$ using a DNA thermocycler (Perkin-Elmer- 
Cetus 9600; Perkin Elmer, Foster City, CA). The reverse transcribed product was used for PCR amplification using the AmpliTaq DNA polymerase enzyme (2.5units) (Perkin Elmer) and the specific upstream and downstream primers at a concentration of $0.1 \mu \mathrm{M}$ each. The primers for mRNA analysis were upper 5'CTCGAAATGGACCCCAA CT3' and lower 5'ATATCTTCGAGCAGGGCTGTC3' yielding a 219-bp product for MT-1A; upper 5' GCTTGTCTTGGCTCCACA3' and lower 5'AGCAAACCGGTCAGG TCAGGTAGTTA3' yielding a 287-bp product for MT-1B; upper 5'GCTTGTTCGTCTC ACTGGTG3' and lower 5'CAGGTTGTGCAGGTTGTTCT3' yielding a 284-bp product for MT-1E; upper 5'AGTCTCTCCTCGGCTTGC3' and lower 5'ACATCTGGGAGAA AGGTTGTC3' yielding a 232-bp product for MT-1F; upper 5'CTTCTCGCTTGGGAA CTCTA3' and lower 5'AGGGGTCAAGATTGTAGCAAA3' yielding a 309-bp product for MT-1G; upper 5'CCTCTTCTCTTGTCGCTTGG3' and lower 5'GCAAATGAGTCG GAGTTGTAG3' yielding a 315-bp product for MT-1H; upper 5'TCTCCTTGCCTCGA AATGGAC3' and lower 5'GGGCACACTTGGCACAGC3' yielding a 151-bp product for MT-1X; upper 5'CCGACTCTAGCCGCCTCTT3' and lower 5'GTGGAAGTCGCG TTCTTTACA3' yielding a 259-bp product for MT-2A; upper 5'CCGTTCACCGCCTC CAG3' and lower 5'CACCAGCCACACTTCACCACA3' yielding a 325-bp product for MT-3; upper 5'CATGGACCCCAGGGAATGTGT3' and lower 5'GGGGTGGGCACGA TGGA3' yielding a 213bp product for MT-4. Primers for glyceraldehyde 3-phosphate dehydrogenase (G3PDH) mRNA were obtained commercially (Clontech, Palo Alto, CA). The thermocycler was programmed to cycle at $95^{\circ} \mathrm{C}$ for 2 min initial step, at $95^{\circ} \mathrm{C}$ for 30 seconds and at $68^{\circ} \mathrm{C}$ for 30 seconds with a final elongation step at $68^{\circ} \mathrm{C}$ for $7 \mathrm{~min}$. Controls for each PCR included a no-template control where water was added instead of 
the RNA and a no-reverse-transcriptase control where water was added instead of the enzyme. Samples were removed at appropriate intervals between 22 and 40 cycles to ensure that the reaction remained in the linear region. The final PCR products were electrophoresed on 2\% agarose gels containing EtBr along with DNA markers. The intensity (integrated optical density, IOD) of the PCR product bands was determined on a Dell workstation configured with Kontron KS 400 image analysis software (Zeiss, Thornwood, NY).

\section{PROTEIN EXTRACTION}

Cells were washed twice with phosphate-buffered saline (PBS) and then lysed in 400uL sodium dodecal sulfate buffer and the cell lysate was stored in tubes in $-70^{0} \mathrm{C}$.

\section{PROTEIN QUANTITATION}

\section{THE ELISA TOTAL PROTEIN ASSAY USING THE BCA COPPER REDUCTION METHOD}

Protein concentrations were determined by the BCA protein assay (Pierce Chemical Co., Rockford, IL). 0.5, 1, 2, 4, 6, 8, $10 \mu \mathrm{g}$ BSA were chosen as the standards for this assay. $100 \mathrm{uL}$ of each of these standards was made. In a flat bottom 96 well plate, $5 \mathrm{ul}$ of SDS lysis buffer and $10 \mu \mathrm{L}$ of water was added to the first two "blank" wells. $5 \mathrm{uL}$ of SDS lysis buffer and $10 \mu \mathrm{L}$ of standard was added to the corresponding standards wells. $10 \mathrm{uL}$ of water and $5 \mu \mathrm{L}$ of SDS samples was added to corresponding sample wells. $200 \mu \mathrm{L}$ of BCA reagent (50:1 BCA solution: $\left.\mathrm{CuSO}_{4}\right)$ was added to each well and incubated at $37^{\circ} \mathrm{C}$ for one hr. The plate was scanned using a Dynatech MR 5000 plate reader (Dynatech Inc., Guernsey Channel Island). 
Final protein concentration $=\underline{\text { Protein concentration obtained in the print out }}$

Volume of sample $(5 \mu \mathrm{L})$

\section{MT PROTEIN DETERMINATION}

MT protein was detected by immunoblotting using a mouse anti-horse antibody (DAKO-MT, E9, Dako, Carpinteria, CA) as the primary antibody. This antibody detects both the MT-1 and MT-2 isoforms, and the product detected is referred to as MT-1/2 in this report. MT-3 protein was detected by immunoblotting using an antibody against human MT-3 as the primary antibody.

Aliquots of $3 \mu \mathrm{g}$ total protein were diluted to $75 \mu \mathrm{l}$ in SDS buffer and mixed with $75 \mu 1$ of $3 \%$ glutaraldehyde to enhance the detection of MT. $100 \mu$ of this mixture ( $2 \mu \mathrm{g}$ of total protein) were applied to a dot blot apparatus with polyvinylidine difluoride membrane. Samples were allowed to flow through the apparatus by gravity, followed by two $100 \mu 1$ PBS washes. After blocking with $10 \%$ skim milk in PBS for MT1/2 protein, the membrane was washed three times in PBS for 10 min. The membrane was soaked in the primary antibody (1:100 dilution, 1\% BSA in PBS) for 2 hrs. The membrane was washed three times in PBS for 10 min each before anti mouse alkaline phosphatase conjugated secondary antibody (Promega, Madison, WI) was added (1:500 dilution, $0.4 \%$ BSA in PBS). The membrane was washed again three times with PBS for 10 min each and then washed with alkaline phosphate buffer for 10 min. Antibody complexes were then visualized using the alkaline phosphate kit III (Vector laboratories, Burlingame, CA) by adding 10 drops each of tubes labeled $1,2, \& 3$, respectively. Rabbit liver $\mathrm{Cd} / \mathrm{Zn}$ metallothionine-1 (Sigma Chemical Co., St. Louis, MO) was applied to each blot to generate standard curves. MT-1/2 protein was quantified by comparing the optical 
density of the sample dots to that of the standard MT curve, using image analysis software (KS- 400, Kontron, Zeiss, Thornwood, NY). This assay has detection limits in the range of $0.1-0.5 \mathrm{ng}$ MT-1/2 protein.

MT-3 protein was detected by immunoblotting using an antibody against human MT-3 as the primary antibody. Aliquots of $3 \mu \mathrm{g}$ total protein were diluted to $75 \mu \mathrm{l}$ in SDS buffer and mixed with $75 \mu 1$ of $3 \%$ glutaraldehyde to enhance the detection of MT. $100 \mu 1$ of this mixture (2 $\mu \mathrm{g}$ of total protein) were applied to a dot blot apparatus with polyvinylidine difluoride membrane. Samples were allowed to flow through the apparatus by gravity, followed by two $100 \mu$ PBS washes. The membrane is blocked with 3\% BSA in PBS then soaked in primary antibody $(4.5 \mu \mathrm{g} / \mathrm{ml}, 1 \%$ BSA in PBS) for $2 \mathrm{hrs}$. The membrane was washed three times in PBS for 10 min each and then soaked in alkaline phosphatase-conjugated secondary antibody (Promega, Madison, WI) at a 1:500 dilution. Antibody complexes were then visualized using the alkaline phosphate kit III (Vector laboratories, Burlingame, CA) by adding 10 drops each of tubes labeled 1, 2, \& 3, respectively. Standard curves of the synthetic peptide (GGEAAEAEAEKC) conjugated to BSA were applied to each blot. MT-3 protein was quantified by comparing the optical density of the sample dots to the standard MT-3 curve, using image analysis software (KS- 400, Kontron, Zeiss, Thornwood, NY). This assay has detection limits in the range of $0.5-2 \mathrm{pg}$ MT-3 protein. 


\section{RESULTS}

\section{7-B1 CELL GROWTH}

The growth rate of the 267-B1 cells was accomplished by subculturing at 20,000 cells/well in a six-well plate and monitored the growth by the automated counting of DAPI-staining nuclei from day 1 to day 10 . The increase in cell number is depicted in Figure 2. From this data, the doubling time was calculated to be 38.33 hours similar to a doubling time of $35.5 \pm 2.5$ hours in PC-3, prostate cancer cells.

\section{MT-mRNA AND PROTEIN EXPRESSION IN THE 267-B1 CELL}

\section{LINE}

MT-1A: The initial experimental goal was to define the basal level of MT-1A mRNA expression in normal human prostate cells not exposed to any metals. The mRNA expression for the housekeeping gene G3PDH was used as a comparison for MT-1A mRNA expression. The reactions were stopped and samples removed for analysis at 30 , 35, and 40 PCR cycles. No expression of MT-1A was demonstrated under basal conditions even at 40 PCR cycles. This is in contrast to G3PDH, where the same total RNA input demonstrated a reaction product corresponding to G3PDH mRNA at 30 PCR cycles (Fig 3). These findings indicate that 267-B1 cells have no basal expression of MT1A mRNA. The effect of $\mathrm{Cd} 2+$ on the expression MT-1A mRNA was also determined on these cells after maintaining in serum-free medium following exposure to $18 \mu \mathrm{M}$ cadmium for 4 hours (Fig 4). An appearance of MT-1A mRNA was observed between 2 hour exposure and 16 hour recovery.

MT-1E: The basal expression of MT-1E mRNA was evaluated using the total RNA samples described above. Results demonstrated that basal expression of MT-1E mRNA 
was evident in 30 PCR cycles for the 267-B1 cell isolates. Product intensities were about one-half of that noted for the G3PDH housekeeping gene at an identical cycle number (Fig 3). The effect of cadmium on the expression of MT-1E mRNA was also determined for the 267-B1 cell isolates. Results showed three fold increase in induction of MT-1E mRNA upon exposure to cadmium and dropped back to basal levels in the recovery phase where the cells were maintained in the serum-free normal medium. $\left(\mathrm{Cd}^{2+}\right.$ free) (Fig $5)$.

MT-1F: The basal level of MT-1F mRNA expression was also assessed in the 267-B1 cells. MT-1F mRNA, like MT-1A mRNA, was shown to be a rare transcript in the 267B1 cells even at 40 PCR cycles. This is in contrast to G3PDH where the same total RNA input demonstrated a convincing reaction product corresponding to G3PDH mRNA at 30 PCR cycles (Fig 3). The MT-1F mRNA expression was determined for cells maintained in serum-free medium following exposure to $18 \mu \mathrm{M} \mathrm{Cd}^{2+}$ for $4 \mathrm{hrs}$. Results showed an appearance of the MT-1F mRNA expression which plateaued at $4 \mathrm{hr}$ of exposure and $4 \mathrm{hr}$ of recovery following the exposure to the metal at which time it gradually falls back to nearly undetectable levels (Fig 6).

MT-1G: No basal expression of MT-1G mRNA was demonstrated under basal conditions even at 40 PCR cycles. This is again in contrast to G3PDH, where the same total RNA input demonstrated a convincing reaction product corresponding to G3PDH mRNA at 30 PCR cycles (Fig 3). The effect of $\mathrm{Cd}^{2+}$ on MT-1G mRNA expression was also determined, and the results showed a considerable increase in expression especially at $4 \mathrm{hr}$ exposure. Expression fell back to undetectable levels before the recovery phase was completed (Fig 7). 
MT-1X: Basal expression of MT-1X mRNA was evident at 30 PCR cycles, about onethird to that noted for G3PDH (Fig 3). The effect of $\mathrm{Cd}^{2+}$ on the MT-1X mRNA expression was determined and results revealed a near two fold induction in mRNA at only $4 \mathrm{hr}$ exposure $4 \mathrm{hr}$ recovery (Fig 8).

MT-2A: Basal expression of MT-2A mRNA was evident at 25 PCR cycles and prominent at $30 \mathrm{PCR}$ cycles. This expression is similar to expression for G3PDH for the 267-B1 cells (Fig 3). The effect of $\mathrm{Cd}^{2+}$ on Mt-2A mRNA showed a slight increase in the induction of MT-2A mRNA expression, regaining back to basal levels in the recovery phase where the cells were maintained in the normal medium for next 48 hours (Fig 9).

MT-3: Basal expression of MT-3 mRNA was evaluated for the 267-B1 cells using the total RNA samples. Results showed that the basal expression of MT-3 mRNA was very little even at 40 PCR cycles (Fig 3). This was in contrast to G3PDH, where the same total RNA input demonstrated a convincing reaction product corresponding to G3PDH mRNA at 30 PCR cycles. In contrast to the results for other isoforms described above, exposure to $\mathrm{Cd}^{2+}$ did not induce any increase in the accumulation of MT-3 mRNA. These results indicated that MT-3 mRNA contributes very little towards total MT mRNA in 267-B1 cells and that the level of expression of MT-3 is not increased due to $\mathrm{Cd}^{2+}$ exposure (Fig 10).

Determination of MT-1/2 protein content in the 267-B1 cell line was done by immunoblotting a mouse anti-horse antibody (DAKO-MT, E9, Dako, Capinteria, CA) as the primary antibody. This antibody detects both the MT-1 and MT-2 isoforms, and the product detected is referred to as MT1/2. The basal level of MT1/2 protein in the 267-B1 cell line was detected to be $3.20 \pm 0.17 \mathrm{ng} / \mu \mathrm{g}$ protein. Upon exposure of cells to $\mathrm{Cd}^{2+}$ for 4 
hours, followed by 48 hours of recovery phase in the normal medium, the results demonstrated an increase in protein content with $16.11 \pm 2.58 \mathrm{ng} / \mu \mathrm{g}$ protein at $12 \mathrm{hr}$ of recovery and regaining back to basal levels by 48 hours of recovery. Results show that MT1/2 protein in 267-B1 cells is supported by transcription of mRNA primarily from MT-1E, MT-1X, and MT-2A and supported minorly by transcription of mRNA from MT-1A, and MT-1F (Fig 11).

MT-3 protein was detected by immunoblotting using an antibody against human MT-3 as the primary antibody. No MT-3 protein at the basal level was detected in the 267-B1 cell line (Fig 3). Upon exposure of cells to $\mathrm{Cd}^{2+}$ for 4 hours, followed by 48 hours of recovery phase in normal medium, the results no significant MT-3 protein level as a result of $\mathrm{Cd}^{2+}$ exposure (Fig 10).

MT-1B, MT-1H AND MT-4: Basal expression and metal-induced expression of mRNA for the MT-1B, MT-1H and MT-4 genes were also determined using the above RNA samples. No expression of MT-1B, MT-1H, and MT-4 mRNA was demonstrated under basal conditions or after treatment with $\mathrm{Cd}^{2+}$. 


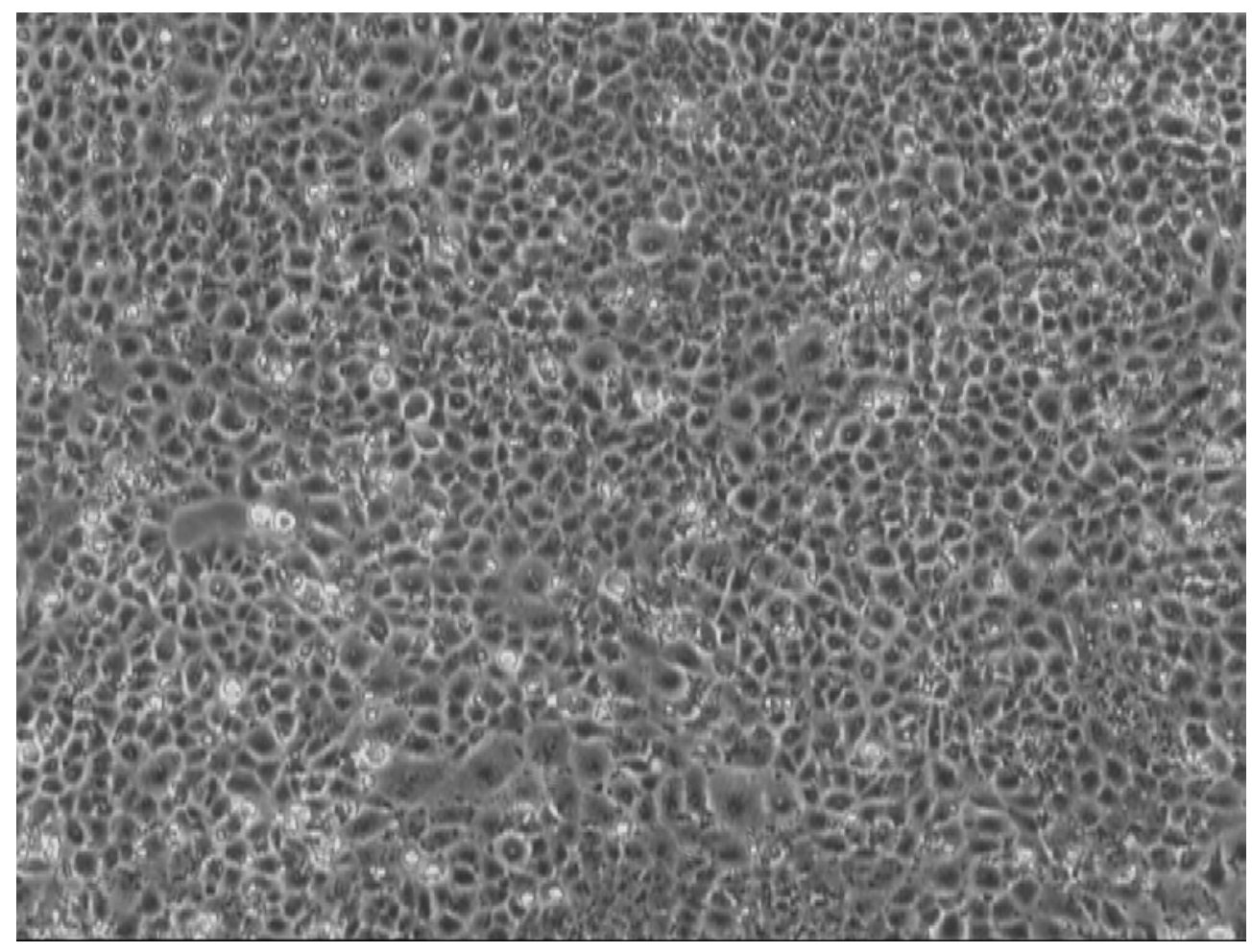

Figure 1 Phase-contrast photomicrograph of 267-B1 cells. Confluent monolayer of 267-B1 normal neonatal prostate cells maintained in P4-8F serum-free growth medium. 


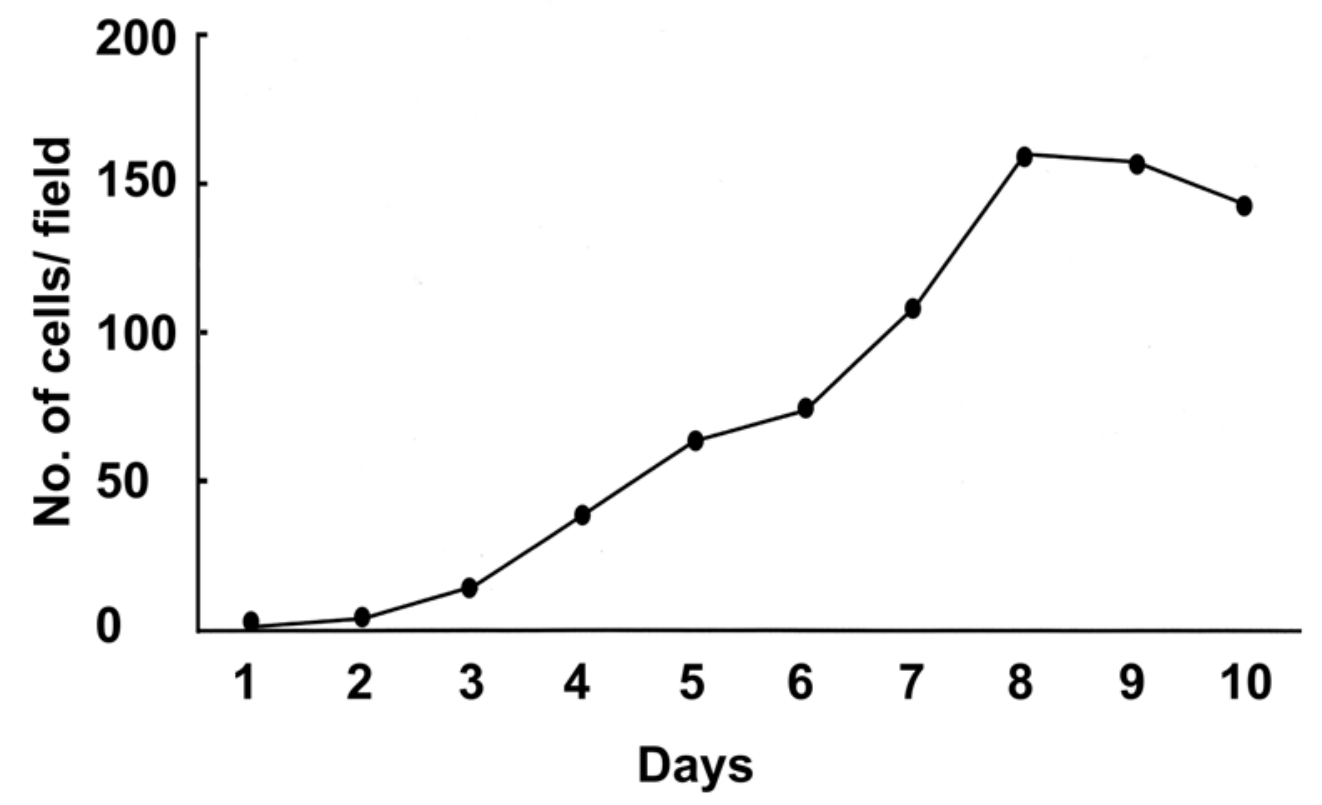

Figure 2 Growth curve of 267-B1 cells. Confluent monolayer of 267-B1 normal neonatal prostate cells maintained in $\mathrm{P} 4-8 \mathrm{~F}$ serum-free growth medium. 


\section{0}

\section{G3PDH}

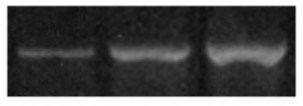

MT-1A

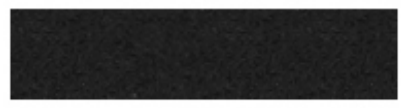

MT-1B

MT-1E
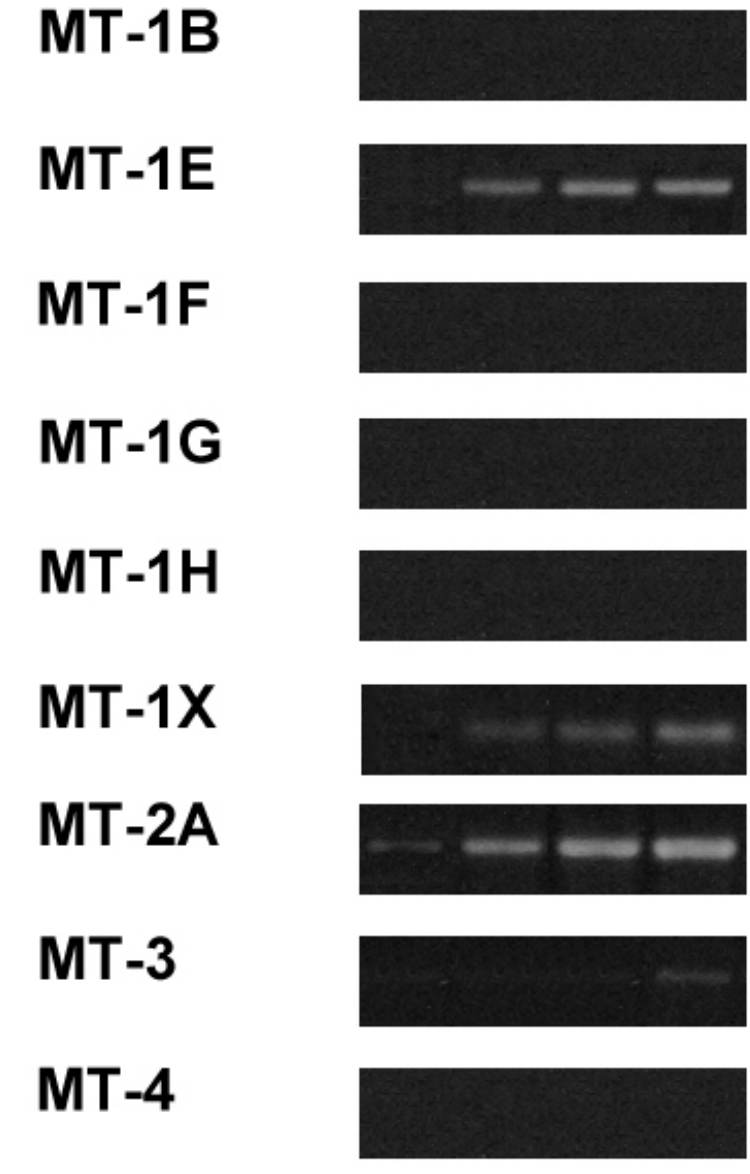

Figure 3 Basal MT gene expression determined by RT-PCR using total RNA from 267-B1 cells. Total RNA was purified from the 267-B1 cells and subjected to RT-PCR using primers specific for G3PDH, MT-1A, MT-1B, MT-1E, MT-1F, MT-1G, MT-1H, MT-1X, MT-2A, MT-3, and MT-4. The reactions were sampled at 25, 30, 35, 40 cycles and the products visualized on $2 \%$ agarose gel containing $0.25 \mu \mathrm{g}$ per $\mathrm{ml}$ ethidium bromide. 

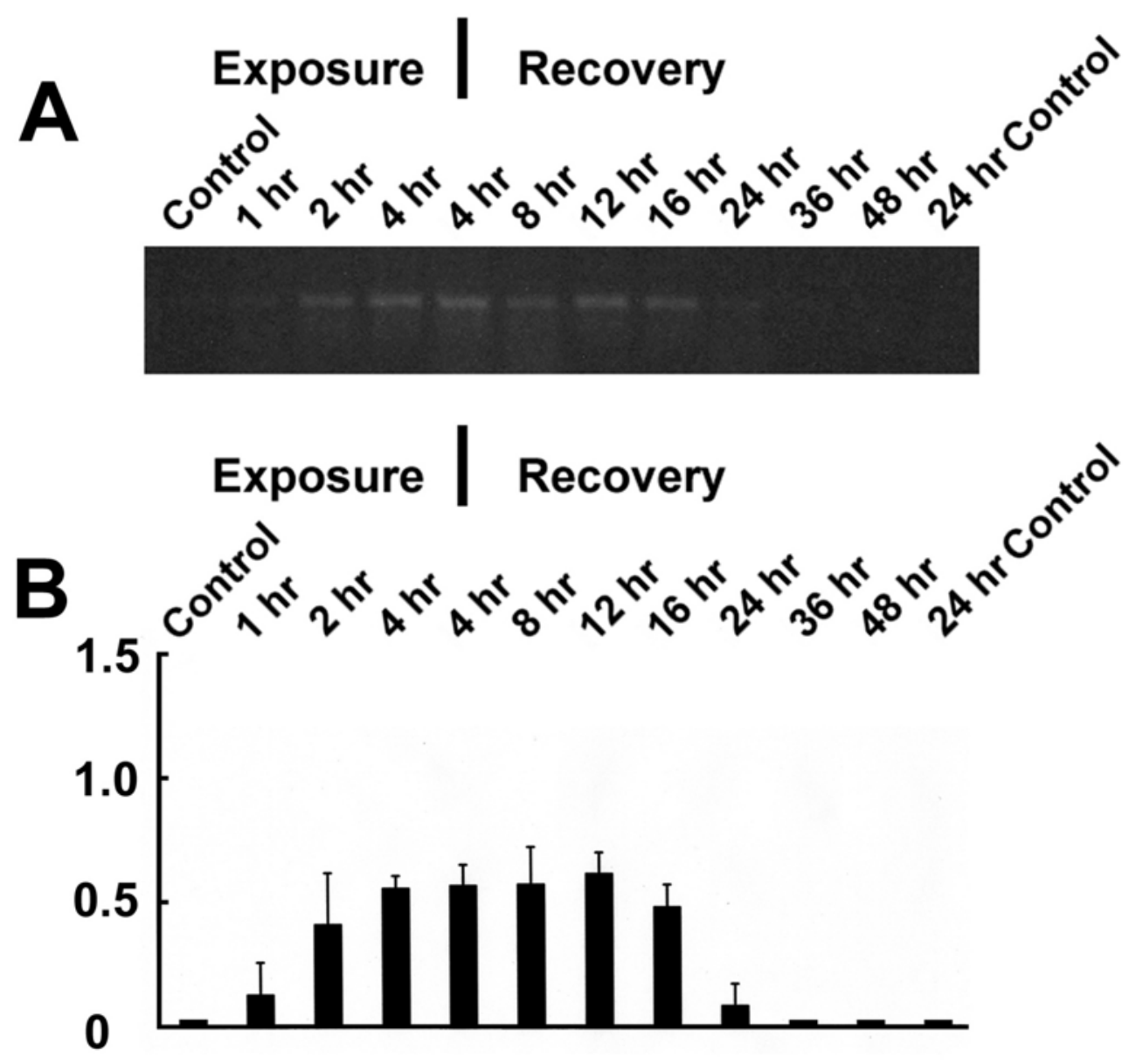

Figure 4 Expression of MT-1A in 267-B1 cell line maintained in serum-free growth medium following exposure to $18 \mathrm{mM}$ cadmium for four hours. A) RT-PCR analysis of MT-1A (40 cycles). Gel shows gene expression at various time points during exposure and recovery from exposure to cadmium. B) Mean IOD values (+SEM) for MT-1A gene expression. 

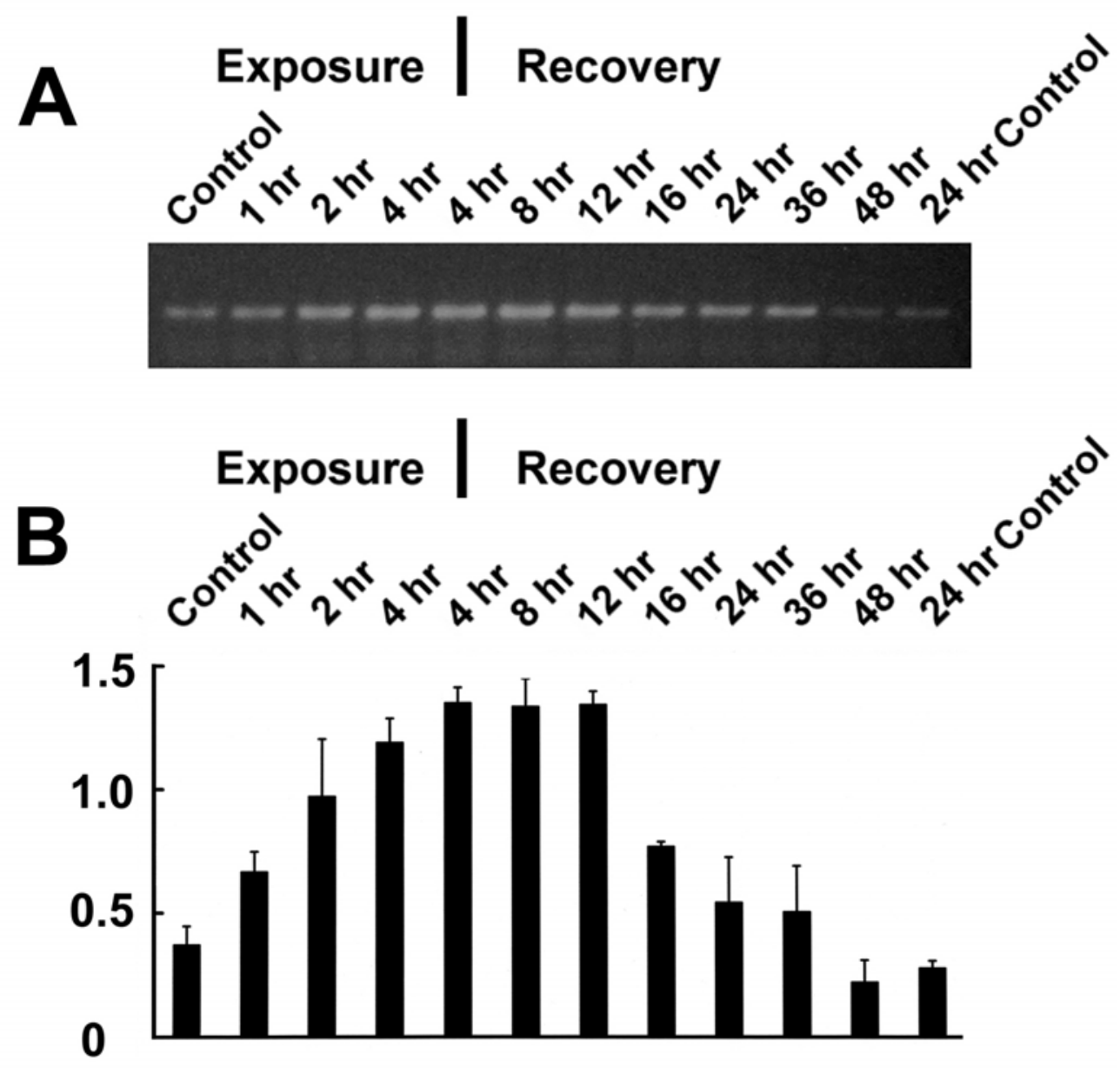

Figure 5 Expression of MT-1E in 267-B1 cell line maintained in serum-free growth medium following exposure to $18 \mathrm{mM}$ cadmium for four hours. A) RT-PCR analysis of MT-1E (30 cycles). Gel shows gene expression at various time points during exposure and recovery from exposure to cadmium. B) Mean IOD values (+SEM) for MT-1E gene expression. 

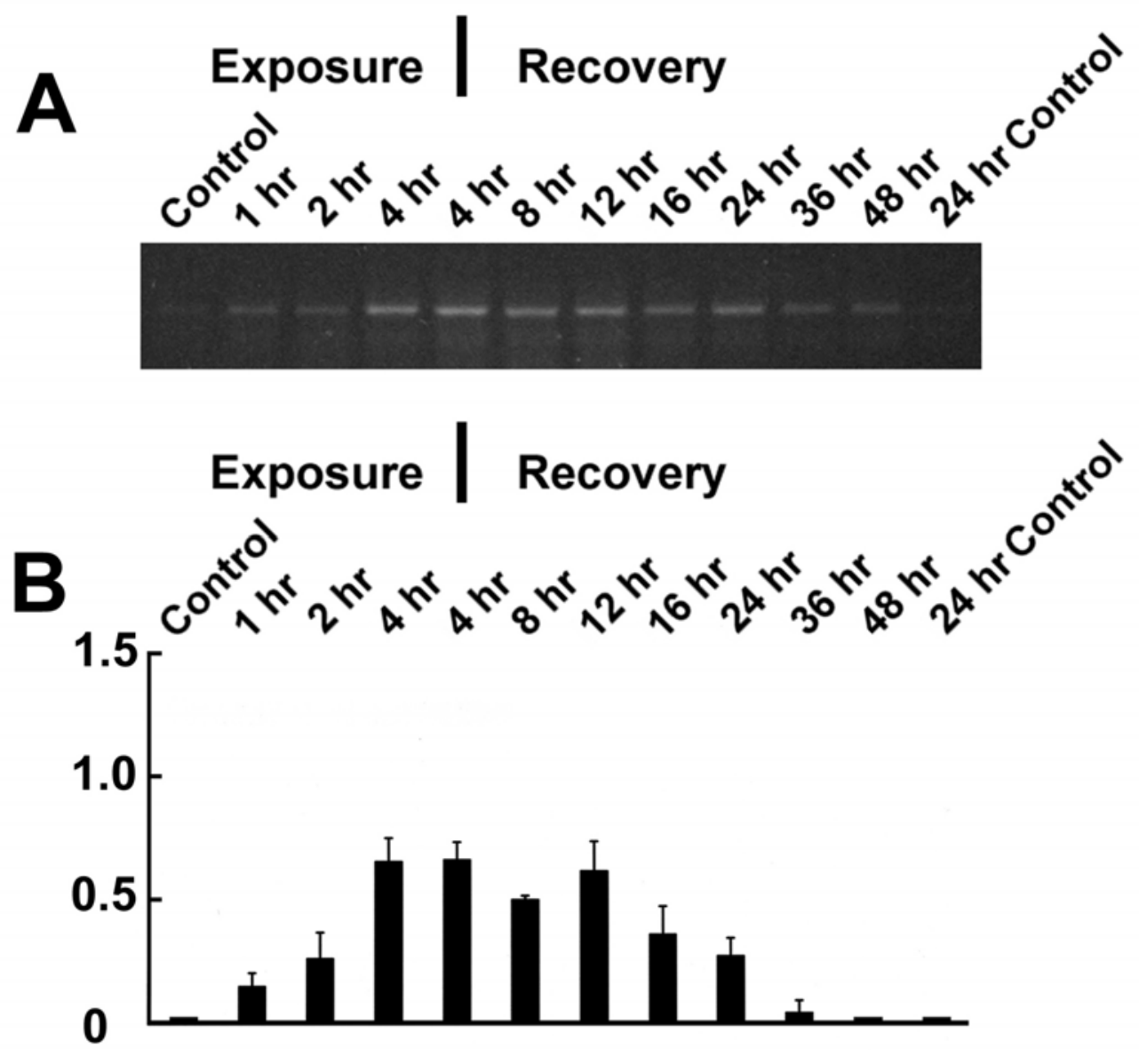

Figure 6 Expression of MT-1F in 267-B1 cell line maintained in serum-free growth medium following exposure to $18 \mathrm{mM}$ cadmium for four hours. A) RT-PCR analysis of MT-1F (40 cycles). Gel shows gene expression at various time points during exposure and recovery from exposure to cadmium. B) Mean IOD values (+SEM) for MT-1F gene expression. 

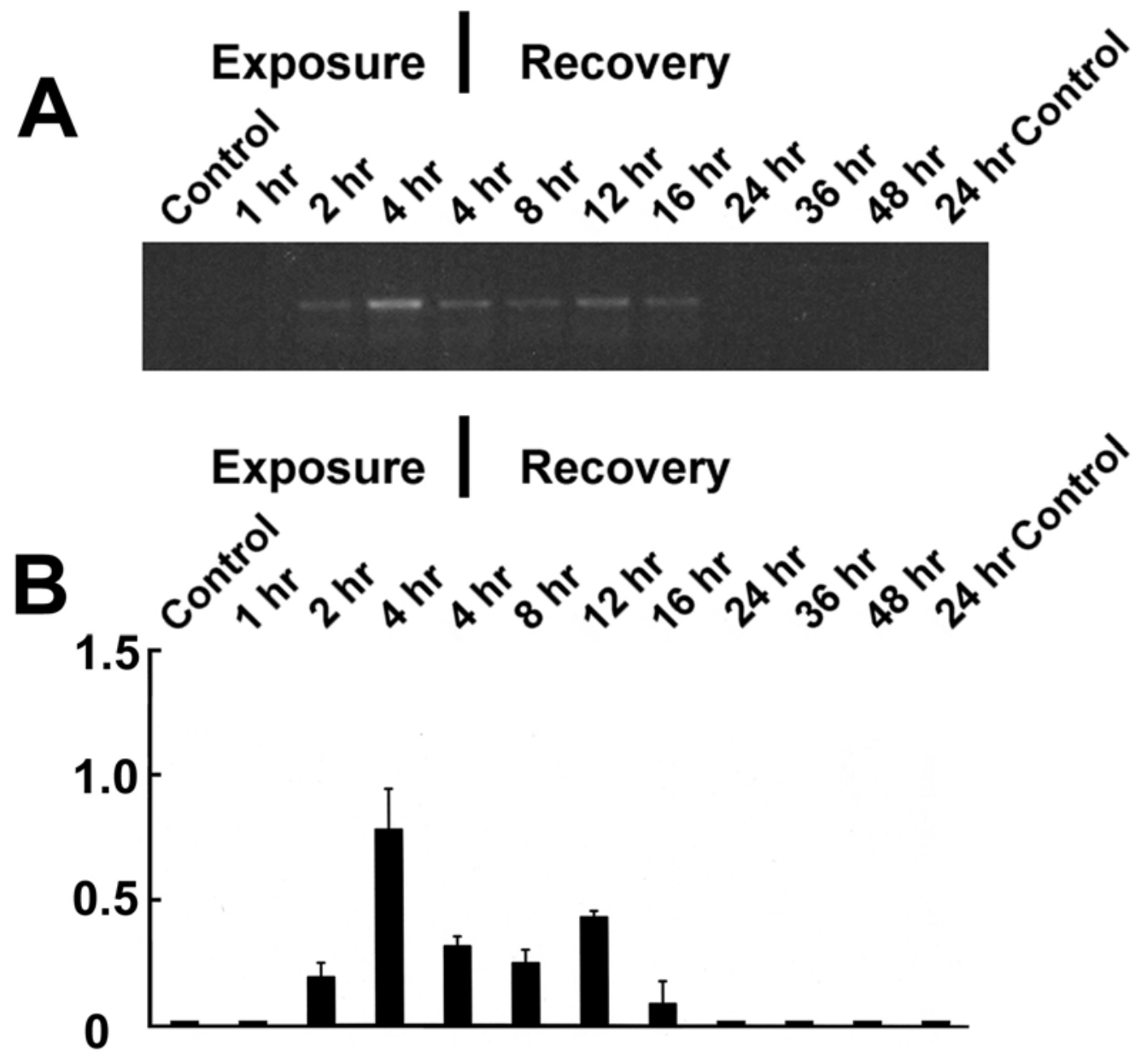

Figure 7 Expression of MT-1G in 267-B1 cell line maintained in serum-free growth medium following exposure to $18 \mathrm{mM}$ cadmium for four hours. A) RT-PCR analysis of MT-1G (40 cycles). Gel shows gene expression at various time points during exposure and recovery from exposure to cadmium. B) Mean IOD values (+SEM) for MT-1G gene expression. 

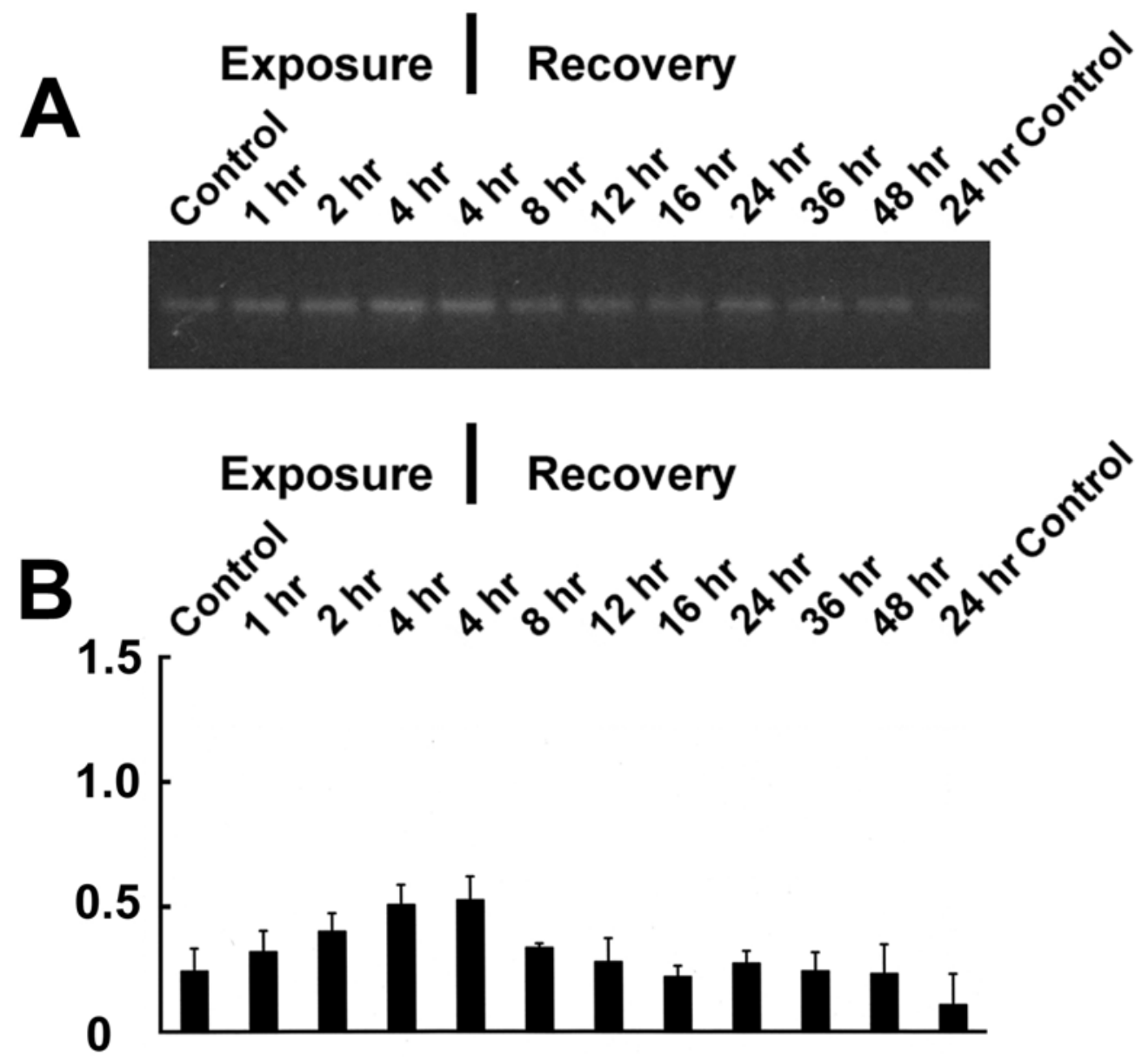

Figure 8 Expression of MT-1X in 267-B1 cell line maintained in serum-free growth medium following exposure to $18 \mathrm{mM}$ cadmium for four hours. A) RT-PCR analysis of MT-1X (40 cycles). Gel shows gene expression at various time points during exposure and recovery from exposure to cadmium. B) Mean IOD values (+SEM) for MT-1X gene expression. 

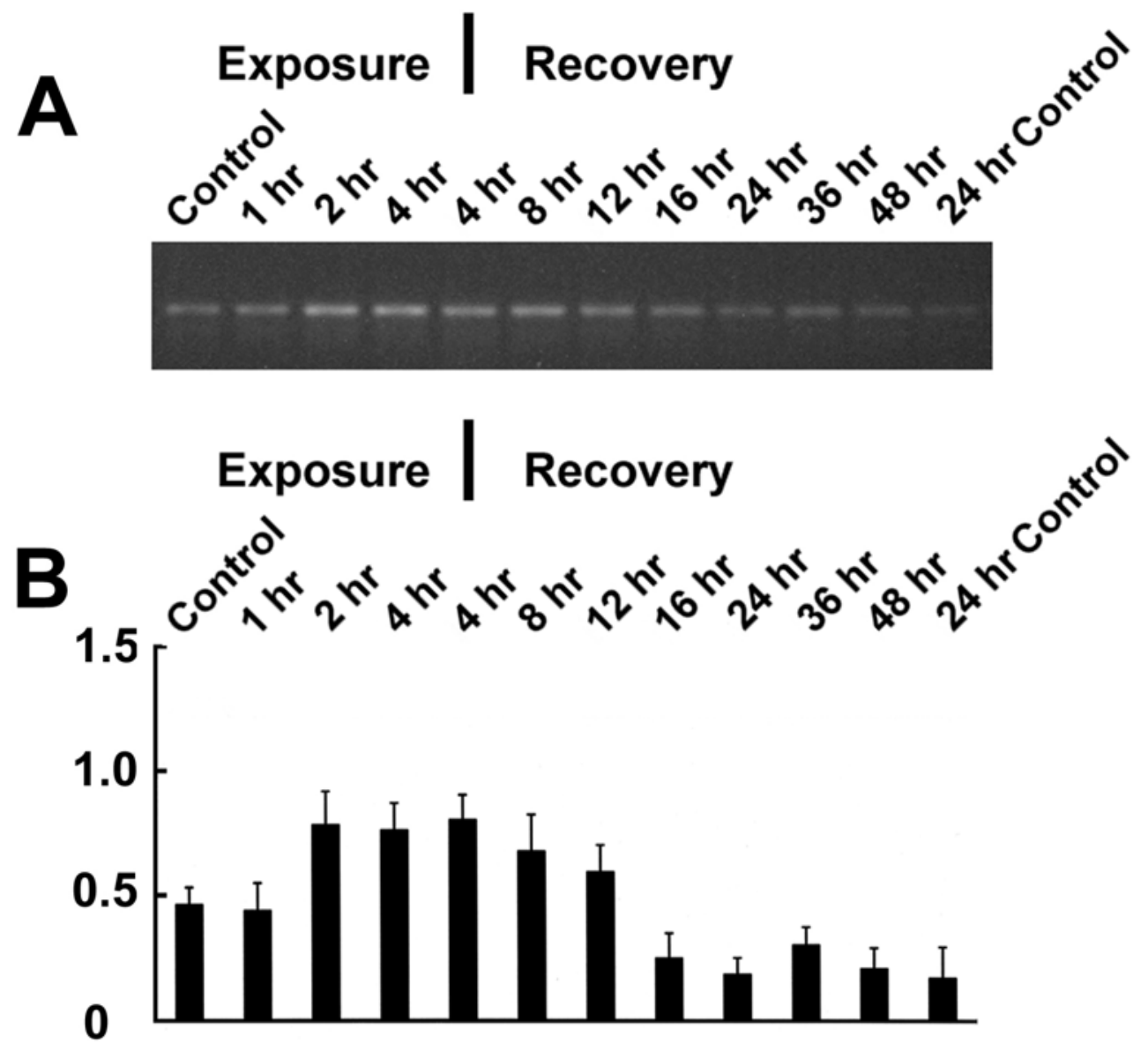

Figure 9 Expression of MT-2A in 267-B1 cell line maintained in serum-free growth medium following exposure to $18 \mathrm{mM}$ cadmium for four hours. A) RT-PCR analysis of MT-2A ( 25 cycles). Gel shows gene expression at various time points during exposure and recovery from exposure to cadmium. B) Mean IOD values (+SEM) for MT-2A gene expression. 

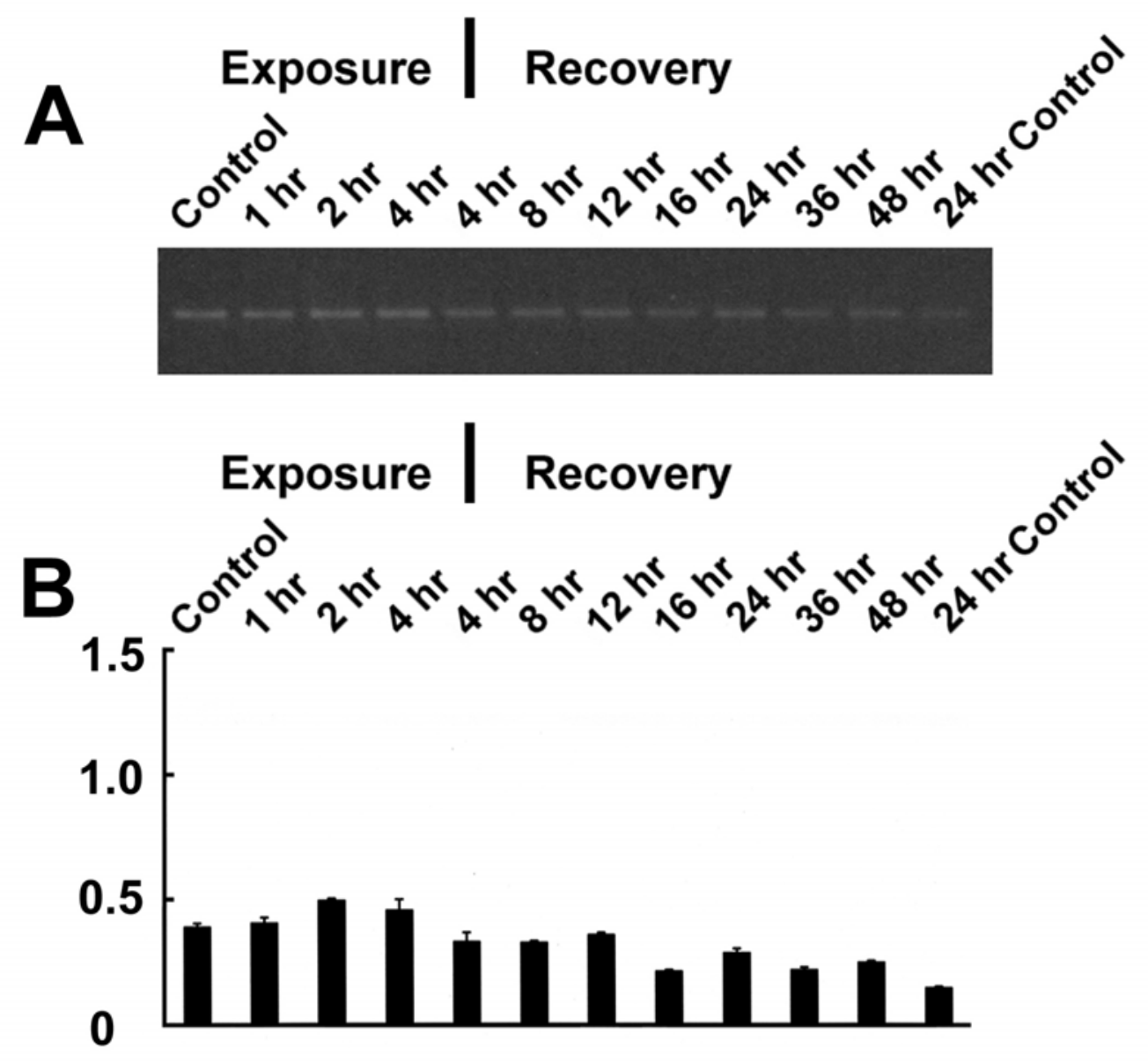

Figure 10 Expression of MT-3 in 267-B1 cell line maintained in serum-free growth medium following exposure to $18 \mathrm{mM}$ cadmium for four hours. A) RT-PCR analysis of MT-3 (40 cycles). Gel shows gene expression at various time points during exposure and recovery from exposure to cadmium. B) Mean IOD values (+SEM) for MT-3 gene expression. 


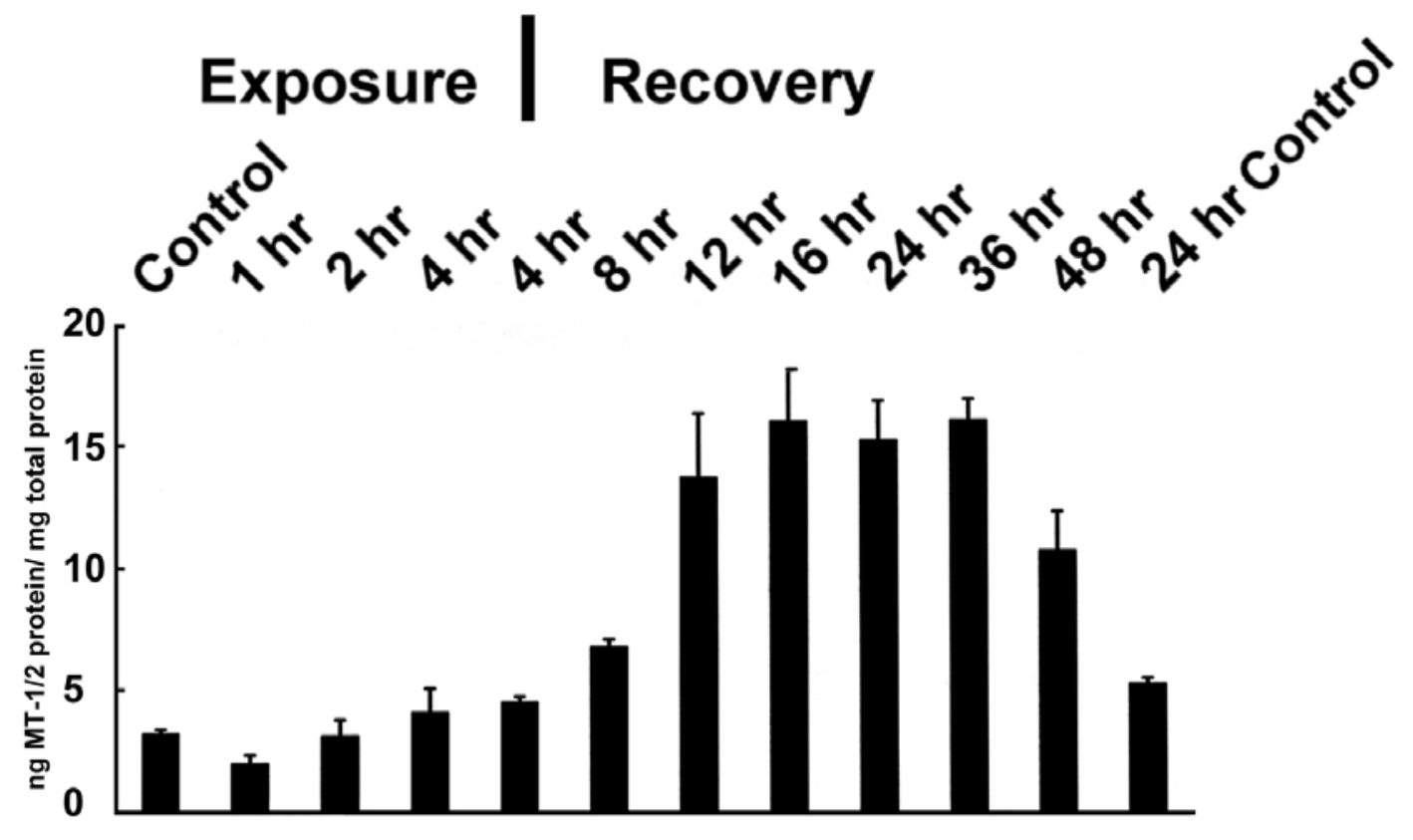

Figure 11 Expression of MT-1/2 protein in 267-B1 cell line maintained in serum-free growth medium following exposure to $18 \mathrm{mM}$ cadmium for four hours. IOD of bands represent MT1/2 protein. 


\section{DISCUSSION}

The objective of this study was to characterize the basal level expression of all the MT-isoforms in the 267-B1 normal prostate cell line and also to observe the expression of the MT- isoforms in response to cadmium exposure. An analysis of basal level MT mRNA expression in the 267-B1 cells demonstrated the expression of mRNA representing the MT-1E, MT-1X, MT-2A, and MT-3 genes. The MT-3 mRNA expression levels were lower than the rest of the isoforms expressed. The basal levels of the MT-1E, MT-1X, and MT-2A isoforms were similar to the expression of the G3PDH house-keeping gene, where as mRNA for MT-1A, MT-1B, MT-1F, MT-1G, MT-1H and MT-4 showed no basal expression. An analysis of MT mRNA expression in human proximal tubule cells demonstrated the expression of mRNA representing MT-1E, MT1X, MT-2A, and MT-3 as the most common transcripts, having expression levels similar to the G3PDH house keeping gene, while mRNA for the MT-1A and MT-1F genes were demonstrated to be less abundant (35). Another study done by Garrett and Sens M.A et al indicated the basal expression of MT-1A, MT-1E, MT-1F, MT-1X, MT-2A and MT-3 genes in the normal human prostate $(31,34)$. The expression of mRNA in the normal human prostate tissue for MT-1X and MT-2A isoforms had the highest expression when compared to MT-1A, MT-1E, and MT-1F (31). The results for MT-3 mRNA genes in the normal human prostate indicated that the level of expression, while not rare, was below that of the 2 commonly monitored housekeeping genes (34). Comparing the findings between the human proximal tubule cells, the normal human prostate tissue and the 267B1 cells, it can be said that the 267-B1 cells retained the expected pattern of MT mRNA expression. 
Determination of MT-1/2 protein content of the 267-B1 cells by immunoblot was observed to be $3.20 \pm 0.17 \mathrm{ng} \mathrm{MT} / \mu \mathrm{g}$ total protein. These protein levels are close to the levels obtained in the six normal prostate tissue specimens which demonstrated to have a range of MT-1/2 expression that varied from a low of $2.99 \pm 0.19 \mathrm{ng} \mathrm{MT} / \mu \mathrm{g}$ total protein to a high of $8.71 \pm 0.13 \mathrm{ng} \mathrm{MT/ \mu g}$ total protein (31). There was no MT-3 protein content in the 267-B1cells compared to the MT-3 protein expression in the normal prostate tissue which had a range of expression varying from a low of $4.0 \mathrm{pg} \mathrm{MT} / \mu \mathrm{g}$ total protein to a high of $24.6 \mathrm{pg} \mathrm{MT/ \mu g} \mathrm{total} \mathrm{protein} \mathrm{(34).}$

We also observed the effect of cadmium on the expression of the different MTisoforms in the 267-B1 cells by exposing the cells to $18 \mu \mathrm{M} \mathrm{Cd}^{2+}$ for four hours followed by rescue in normal serum free growth medium. In total RNA preparation from 267-B1 cells exposed to $\mathrm{Cd}^{2+}$, mRNA for the MT-1E showed a three fold induction, mRNA for the MT-1X showed a two fold induction, MT-1A, MT-1F, MT-1G genes were demonstrated to have a considerable increase in induction, while the mRNA for MT-2A gene compared to the others isoforms showed only a slight increase in expression. This difference in induction of MT-2A can be compared with the findings in a previous study of human proximal tubule cells, where it was shown that human proximal tubule cells exposed to $\mathrm{Cd}^{2+}$ had no corresponding increase in the amount of MT-2A mRNA (37). In contrast to the increase in mRNA for only the MT-1A and MT-1E genes in the human proximal tubule cells exposed to $\mathrm{Cd}^{2+}$, the $267-\mathrm{B} 1$ cells showed a considerable $\mathrm{Cd}^{2+}$ induction for MT-1A, MT-1E, MT-1F, and MT-1G genes. All four isoforms showed a gradual increase in mRNA expression with the highest induction being at $4 \mathrm{hr}$ exposure and recovering back to the basal levels within $24 \mathrm{hr}$ after rescuing the cells in the normal 
serum free growth medium. The expression of the MT-1/2 protein content in the $267-\mathrm{B} 1$ cells showed a gradual increase upon $\mathrm{Cd}^{2+}$ exposure, but more protein accumulation was seen in the following $16 \mathrm{hr}$ recovery phase with $16.11 \pm 2.58 \mathrm{ng} \mathrm{MT} / \mu \mathrm{g}$ total protein being the highest level of protein expression.

The effect of $\mathrm{Cd}^{2+}$ on the expression of MT-3 mRNA was also determined for the 267-B1 cells. Results showed no increase in the level of MT-3 mRNA expression. MT-3 expression is reported to be mainly in the brain and findings from a study demonstrate that MT-3 mRNA levels in the testis, epididymis, prostate and tongue were only $22 \%$ of those in the brain (36). It was also shown that MT-3 gene was not inducible by $\mathrm{CdCl}_{2}$ in rat testis and prostate. In human, relative MT-3 mRNA levels were lower than those found in the rat. However, in contrast, induction of MT-3 mRNA was shown to occur in cultures of the human proximal tubule cells when exposed to $\mathrm{Cd}^{2+}$ and $\mathrm{Zn}^{2+}$ (10). Studies also indicate that MT-3 immunoreactivity is elevated in PIN lesions and in primary prostate cancer cells suggesting a possible dysregulation of MT-3 expression in prostate cancer. While DU-145 and LNCaP prostate cancer cell lines were demonstrated to express mRNA for MT-3, the PC-3 cell line demonstrated no expression for MT-3. This variable nature of MT-3 expression suggests an area of further study.

In conclusion, the patterns of induction are quite different between MT-1, MT-2 and MT-3 gene family and also different between organs and tissues. Further determination of the expression levels of individual MT-1 and MT-2 isoform- specific proteins would allow the determination of the relative contributions of the MT proteins. Newly developed MT-null cells can be used to conduct transfections by expressing vectors containing each human MT isoforms- specific gene, and study the expression 
levels and functional properties of each specific MT isoforms protein. Furthermore, this 267-B1 cell line would serve as an excellent recipient of stable trasfection of a vector over-expressing the MT-3 gene to model the consequences of MT-3 over-expression seen in prostate cancer. This cell line also serves as a non- neoplastic control for the PC-3 prostate cancer cell line, which is being extensively studied in this laboratory. 


\section{APPENDIX}

\section{REAGENTS USED FOR PROTEIN CELL EXTRACTS}

2\% SDS BUFFER (50mM Tris, pH 6.8; 2\% w/v SDS).

1 gram of Sodium Dodecal Sulfate (SDS) is combined with $50 \mathrm{ml}$ of $50 \mathrm{mM}$ Tris $\mathrm{Cl}$ $(\mathrm{pH}=6.8)$ in a tube and placed on a rocker for at least one hour until SDS is completely dissolved.

PRIMARY ANTIBODY (1:100) FOR MT-1/2 MONOCLONAL MOUSE ANTIHORSE MT (DAKO-MT, E-9)

- $\mathrm{MT}$ Ab, E9 from DAKO - (1:100)

- $\operatorname{BSA}(1 \%)$

- $\mathrm{NaN}_{3}(0.02 \%)$

- $\quad$ PBS to $45 \mathrm{ml}$

SECONDARY ANTIBODY (1:500) FOR MT-1/2 ANTI MOUSE AB IgG

(Promega)

- Anti-mouse Ab IgG - (1:500)

- $\operatorname{BSA}(0.4 \%)$

- $\mathrm{NaN}_{3}(0.02 \%)$

- $\quad$ PBS to $45 \mathrm{ml}$

PRIMARY ANTIBODY (1:400) FOR MT-3

- $\mathrm{MT}-3 \mathrm{Ab}-(1: 400$ of $0.5 \mu \mathrm{g} / \mathrm{ml})$

- $\operatorname{BSA}(2 \%)$

- $\mathrm{NaN}_{3}(0.02 \%)$

- $\quad$ PBS to $45 \mathrm{ml}$ 


\section{SECONDARY ANTIBODY (1:500) ANTI-RABBIT}

- Anti-rabbit Ab - (1:500)

- $\operatorname{BSA}(0.4 \%)$

- $\mathrm{NaN}_{3}(0.02 \%)$

- $\quad$ PBS to $45 \mathrm{ml}$ 


\section{REFERENCES}

1. Hamer D. H. (1986) Metallothionein. Annual Review of Biochemistry 55: 913 951.

2. Kagi, J. H. R and Vallee, B. L. (1960) Metallothionein: A cadmium and zinc containing protein for equine renal and cortex. Journal of Biological Chemistry235: 3460 - 3465.

3. Miles, A. T, Hawlesworth G. M. (2000) Induction, Regulation, Degradation, and Biological significance of Mammalian Metallothionein. Critical Review of Biochemistry and Molecular Biology 35(1): 35 -70.

4. Imagawa, M; Ishikawa, Y; Shimano, H; Osada, S; and Nishihara, T. (1995) CTG triplet repeat in mouse growth inhibitory factor/metallothionein III gene promoter represses the transcriptional activity of the heterologous promoters. Journal of Biological Chemistry 270: $20898-20900$.

5. Palmiter, R. D; Findley, S. D; Whitmore, T. E; and Durnam, D. M. (1992) MTIII, a brain-specific member of the metallothionein gene family. Proceedings of National Academy of Science. U. S. A. 89: 6333 - 6337.

6. Quaife, C. J; Findley, S. D; Erickson, J. C; Froelic, G. J; Kelly, E. J; Zambrowicz, B. P; and Palmiter, R. D. (1994) Induction of a new metallothionein isoform (MTIV) occurs during differentiation of stratified squamous epithelia. Biochemistry 33: $7250-7259$. 
7. Sewell, A. K; Jensen, L. T; Erickson, J. C; Palmiter, R. D; and Winge, D. R. (1995) Bioactivity of metallothionein-3 correlates with its novel beta domain sequence rather than metal binding properties. Biochemistry 34: $4740-4747$.

8. West, A. K; Stallings, R; Hildebrand, C. E; Chiu, R; Karim, M; Richards, R. I. (1990) Human Metallothionein genes; Structure of the functional locus at 16q13. Genomics 8: $513-518$.

9. Stennard, F. A; Holloway, A. F; Hamilton, J; and West, A. K. (1994) Characterization of six additional human metallothionein genes. Biochemica Et Biophysica Acta. 1218: $357-365$.

10. Garrett, S. H; Sens, M. A; Todd, J. H; Somji, S; and Sens, D. A. (1999) Expression of MT-3 protein in the Human Kidney. Toxicology Letters 105: $207-$ 214.

11. Hoey, J. G; Garrett, S. H; Sens, M. A; Todd, J. H; and Sens, D. A. (1997) Expression of Mt-3 mRNA in Human Kidney, Proximal tubule cell cultures, and renal cell carcinomas. Toxicology Letters 92: $149-160$.

12. Kagi, J. H. (1991) Overview of metallothionein. Methods in Enzymology 205: $613-626$

13. Nagel, W. W; and Vallee, B. L. (1995) Cell cycle regulation of metallothionein in human colonic cancer cells. Proceedings of National Academy of Science. U. S. A. $92: 579-583$. 
14. Studer, R; Vogt, C. P; Cavigelli, M; Hunzieker, R. E; and Kagi, J. H. (1997) Metallothionein accretion in human hepatic cells is linked to cellular proliferation. Biochemistry Journal 328: $63-67$.

15. Mididoddi, S; McGuirt, J. P; Sens, M. A; Todd, J. H; and Sens, D. A. (1996) Isoform-specific expression of metallothionein mRNA in the developing and adult human kidney. Toxicology Letters 85:1 17-27.

16. Kondo, Y; Rusnak, J. M; Hoyt, D. G; Settineri, C. E; Pitt, B. R; and Lazo, J. S. (1997) Enhanced apoptosis in metallothionein null cells. Molecular Pharmacology 52: $195-201$.

17. Jasani, B; and Schmid, K. W. (1997) Significance of metallothionein overexpression in human tumors. Histopathology 31:211-214.

18. Kagi, J. H; and Kojima, Y. (1987) Chemistry and biochemistry of metallothionein. Experientia 52: 25-61.

19. Walsh, C. T; Sandstead, H. H; Prasad, H. S; Newberne, P. M; and Franker, P. J. (1994) Zinc: Health effects and research priorities for the 1990s. Environmental Health Perspective 102: $5-46$.

20. Palmiter, R. D. (1998) The elusive function of metallothionein. Proceedings of National Academy of Science. U. S. A. 95: $8428-8430$.

21. Jacob, C; Maret, W; and Vallee, B. L. (1998) Control of zinc transfer between thionein, metallothionein, and zinc proteins. Proceedings of National Academy of Science. U. S. A. 95: 3489 - 3494. 
22. Maret, W; and Vallee, B. L. (1998) Thiolate ligands in metallothionein confer redox activity on zinc clusters. Proceedings of National Academy of Science. U. S. A. $95: 3478-3482$.

23. Freedman, J. H; Ciriolo, M. K; and Peisach, J. (1989) The role of glutathione in copper metabolism and toxicity. Journal of Biological Chemistry 264: 5598 5605.

24. Klaassen, C. D; Liu, J; and Choudhuri, S. (1999) Metallothionein: An intracellular protein to protect against cadmium toxicity. Annual review of Pharmacology and Toxicology 39: $267-294$.

25. Andrews, G. K. (2000) Regulation of metallothionein gene expression by oxidative stress and metal ions. Biochemical Pharmacology 59: 95 - 104.

26. Goering, P. L; and Klaassen, C. D. (1984) Tolerance to cadmium- induced hepatotoxicity following cadmium pretreatment. Toxicology And Applied Pharmacology 74: $308-313$.

27. Goering, P. L; and Klaassen, C. D. (1984) Zinc induced tolerance to cadmium hepatotoxicity. Toxicology And Applied Pharmacology 74: 299 - 307.

28. Liu, Y; Liu, J; Iszard, M. B; Andrews, G. K; Palmiter, R. D. and Klaassen, C. D. (1995) Transgenic mice that overexpresse MT-1 are protected from cadmium lethality and hepatotoxicity. Toxicology And Applied Pharmacology 135: 222 228. 
29. Kondo, Y; Woo, E.S; Michaska, A. E; Chock, H. A; Lazo, J.S. (1995) Metallothionein null-cells have increased sensitivity to anticancer drugs. Cancer Research 55: $2021-2023$.

30. Kelly, S. L; Basu, A; Teichen, B.A; Hacker, H. P, Hamer P.H; Lazo, J.S. (1988) Overexpression of metallothionein confers resistance to anticancer drugs. Science 241: $1813-1815$.

31. Garrett, S. H; Sens, M. A; Deepti, S; Luis, F; Somji, S; Todd, J. H; and Sens, D. A. (2000) Metallothionein isoform 1 and 2 gene expression in the Human Prostate: Down-regulation of Mt-1X in advanced prostate cancer. The Prostate 43: $125-135$.

32. Waalkes, M. P. (2000) Cadmium carcinogenesis in review. Journal of Inorganic Biochemistry 79: $241-244$.

33. Uchida, Y; Talio. K; Titani, K; Ihara,Y; Tomonaga, M. (1991) The growth inhibitory factor that is deficient in Alzheimer's disease is a 68 amino acid metallothionein- like protein. Neuron 7: $337-347$.

34. Garrett, S. H; Sens, M. A; Deepti, S; Luis, F; Somji, S; Todd, J. H; and Sens, D. A. (1999) Metallothionein Isoform 3 Expression in the Human Prostate and Cancer- Derived Cell Lines. The Prostate 41: 196 - 202.

35. Garrett, S. H; Somji, S; Todd, J. H; Sens, M. A; and Sens, D. A. (1998) Differential Expression of Human Metallothionein Isoform 1 mRNA in Human Proximal Tubule Cells Exposed to Metals. Environmental Health Perspectives 106: $825-831$. 
36. Moffatt, P; Seguin, C. (1998) Expression of the gene encoding Metallothionein-3 in organs of the reproductive system. DNA Cell Biology 17(6): 501-510.

37. Garrett, S. H; Somji, S; Todd, J. H; Sens, M. A; and Sens, D. A. (1998) Exposure of Human Proximal Tubule cells to $\mathrm{Cd}^{2+}, \mathrm{Zn}^{2+}$, and $\mathrm{Cu}^{2+}$ Metallothionein protein accumulation but not Metallothionein isoform 2 mRNA. Environmental Health Perspectives 106(9): $587-595$. 


\section{VITA}

\section{Madhuri G. Neriyanuri}

\section{OBJECTIVE:}

To obtain a position in a growing company or a research institution that will allow me to use my technical skills and experience in Genetics and Molecular Biology.

\section{EDUCATION:}

- MS: Genetics and Developmental Biology, West Virginia University (WVU)

Expected March 2002, GPA 3.89

- PG Diploma: Child psychology, Osmania University, Hyderabad, India

- BS: Genetics: Osmania University, Hyderabad, India

April 1999, GPA 3.75

April 1997, GPA 3.8

\section{RESEARCH EXPERIENCE:}

Characterization of Metallothionein gene

West Virginia University, Department of Urology

Dec 2000 - Present

- Characterized mRNA and protein expression of the metallothionine gene in a normal prostate cell line in response to cadmium.

- Techniques used in this project include Cell culture, RT-PCR, Gel electrophoresis, Immunoblotting analysis of Proteins.

- RT-PCR bands and MT protein was quantified using Kontron KS 400 image analysis software.

\section{Characterization of Heat-shock Protein}

West Virginia University, Department of Urology

Jan 2000 - Dec 2000

- Characterized the mRNA and protein expression of heat shock proteins (Hsp 90 $\alpha$ and Hsp90 3 ) in Human Kidney Proximal tubule cells in response to cadmium through RT-PCR and Western Blotting respectively.

\section{Children's Personality Profile}

Osmania University, India. Department of Psychology.

Jan 1998

- Established personality profile of children under the age group of 11 years using various personality and analytical tests.

\section{Association of Leukemia with blood groups}

MNN Cancer Center, India.

Jan

1997

- Investigated the symptoms and evaluated statistically the correlation between the incidence of leukemia and blood groups. 


\section{PROFESSIONAL EXPERIENCE:}

\section{Graduate Research Assistant}

West Virginia University, Department of Urology. Jan 2000 - Present

- Performed many molecular techniques and protocol, and extensive cell culture techniques.

- Characterized the expression of metallothionine gene in response to cadmium.

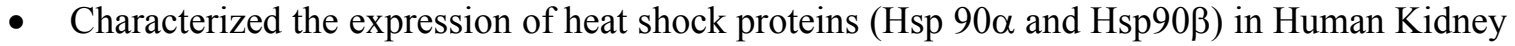
Proximal tubule cells in response to cadmium.

- Performed stable transfection of the MT-3 over-expressing vector in a 267-B1 normal neonatal prostate cell line.

- Determined cell viability by the automated counting of DAPI stained nuclei of fixed cells using Kontron KS 400 image analysis software.

\section{Graduate Teaching Assistant}

West Virginia University, Department of Biology Aug 1999 - May 2001

- Personally responsible for the evaluation of more than 100 students every semester.

- Prepared weekly lectures, conducted laboratory sessions, exams, quizzes, and graded lab reports.

\section{RELEVANT COURSES:}

Basic Concepts of Modern Genetics, Advanced Biochemical Genetics, Cytogenetics, Population Genetics, General Biochemistry, Agricultural Biochemistry, Statistical methods.

\section{RELEVANT SKILLS:}

\section{Laboratory Skills}

DNA and RNA Isolation

Gel Electrophoresis

PCR and PT-PCR

Western Blotting

Immuno Dot- Blot for protein analysis

Cell culture techniques

Transfection

Preparation of media and other required

reagents and chemicals

\section{Computer skills}

Kontron KS 400 image analysis software

Microsoft Word

Microsoft Excel

Microsoft PowerPoint

Adobe Photo Shop 5.1 